\title{
Clomiphene Citrate versus Letrozole for Ovulation Induction in PCOS: A Comparative Study
}

\author{
Sabnam S Nambiar
}

\begin{abstract}
Polycystic ovary syndrome (PCOS) affects $20-33 \%$ of women of reproductive age and the leading cause of infertility. Treatment includes lifestyle modification, metformin, ovulation induction, surgery, in vitro fertilization. Clomiphene citrate is most commonly used for ovulation induction but is antiestrogenic. Clomiphene resistance occurs in $15-20 \%$ of patients. Letrozole, an aromatase inhibitor, inhibits aromatization thus conversion of androstenedione and testosterone to estrogen in the ovary. This releases the hypothalamic/pituitary axis from estrogenic negative feedback, follicle stimulating hormone secretion increases, stimulating ovarian follicular development.
\end{abstract}

We compared clomiphene citrate vs letrozole for ovulation induction in the treatment of anovulatory infertility in women with the polycystic ovarian syndrome. Two hundred consecutive women were observed for a number of cycles required to achieve ovulation, follicular growth, endometrial thickness, dominant follicle size, pregnancy, multiple, and abortion rates. The groups were matched for age, parity, duration of married life, menstrual regularity and prior history of treatment for infertility.

Clomiphene showed a significantly increased number of follicles. Monofollicular development and endometrial thickness were higher in the letrozole group. The difference in dominant follicle size, number of cycles to achieve pregnancy or difference in ovulation rate per cycle, number of pregnancies and pregnancy losses per cycle lacked statistical significance. Greater number of follicles in the clomiphene group did not result in increased pregnancy rate. A number of pregnancies were marginally higher but not statistically significant in the letrozole group. There were one quadruplet and one twin gestation in the clomiphene group with none in the letrozole group. This data was not sufficient for statistical analysis. There were no instances of ovarian hyperstimulation syndrome or congenital anomalies in either group.

Keywords: Clomiphene citrate, Follicle, Infertility, IVF, Letrozole, Pregnancy.

How to cite this article: Nambiar SS. Clomiphene Citrate versus Letrozole for Ovulation Induction in PCOS: A Comparative Study. J South Asian Feder Obst Gynae 2018;10(Suppl 2): 384-399.

\section{Source of support: Nil}

Conflict of interest: None

\section{Assistant Professor}

Department of Obstetrics and Gynaecology, Pariyaram Medical College, Kannur, Kerala, India

Corresponding Author: Sabnam S Nambiar, Assistant Professor, Department of Obstetrics and Gynaecology, Pariyaram Medical College, Kannur, Kerala, India, e-mail: sabnamsn@rediffmail.com
Date of received: 10 April 2017

Date of acceptance: 1 September 2018

Date of publication: July 2019

\section{INTRODUCTION}

Polycystic ovary syndrome (PCOS), also known clinically as Stein-Leventhal syndrome, affects approximately $20-33 \%,{ }^{1-4}$ of women of reproductive age, and is a leading cause of infertility. The symptoms and signs are highly variable. ${ }^{1}$ There may be a familial predilection with studies suggestive of autosomal transmission of genetic sequences. $^{5}$

\section{Clinical Manifestations}

- Obesity, hyperandrogenism, ${ }^{6}$ menstrual irregularities, infertility.

- Increased levels of androgens, ${ }^{7-9}$ LH, FSH, prolactin, estradiol, hyperinsulinemia ${ }^{10-12}$ and decreased the level of sex hormone binding globulin.

- Increased risk of diabetes mellitus, dyslipidemia, hypertension, cardiovascular disease, endometrial carcinoma ${ }^{13}$ and breast carcinoma with advancing age.

\section{DEFINITION}

1. 1990, consensus workshop by NIH/NICHD: ${ }^{14}$

- Hyperandrogenism and/or hyperandrogenemia

- Oligoovulation

- Exclusion of other related disorders, e.g., Cushing's syndrome, $\mathrm{CAH}$, hypothalamic amenorrhea, premature ovarian failure, etc.

2. 2003, consensus workshop by ESHRE/ASRM in Rotterdam indicated PCOS to be present if 2 out of 3 criteria are met: ${ }^{15}$

- Oligoovulation [follicular arrest", i.e., several follicles develop to a size of $5-7 \mathrm{~mm}$, but not further. No single follicle reaches the preovulatory size ( $16 \mathrm{~mm}$ or more)] and/or anovulation.

- Excess androgen activity

- Polycystic ovaries (by gynecologic ultrasound), and other causes of PCOS are excluded.

According to the Rotterdam criteria, 12 or more small follicles should be seen in an ovary on ultrasound examination. The follicles may be oriented in the periphery, 
giving the appearance of a 'string of pearls'. The numerous follicles contribute to the increased size of the ovaries, that is, $1.5-3$ times larger than normal. ${ }^{16}$

3. Androgen Excess Society in 2006 states as PCOS if:

- Hirsutism and/or hyperandrogenemia.6,17-19

- Oligoanovulation and/or polycystic ovaries by ultrasonogram.

- Exclusion of other androgen excess or related disorders.

The Rotterdam definition, however, is more inclusive, unlike NIH/NICHD definition where androgen excess is a prerequisite. Treatment of PCOS should preferably be tailored according to the patient's symptoms. Accordingly, options include weight loss, insulin sensitizers like metformin, ${ }^{20-23}$ ovulation induction ${ }^{24}$ and laparoscopic surgery. ${ }^{25,26}$ Studies to decide the best of these are not available. PCOS is a risk factor for ovarian hyperstimulation syndrome ${ }^{27}$ hence ovulation induction needs careful monitoring with serial ultrasonograms. ${ }^{28}$

Clomiphene citrate and gonadotropins alone or used synergistically as agents of ovulation induction. However, their use is fraught with risks of multiple pregnancies, ${ }^{29,30}$ antioestrogenic effects like hot flushes, breast tenderness, dizziness, nausea, ovarian cysts, multiple pregnancies, OHSS, etc. Search for alternatives has led to the use of aromatase inhibitors, e.g., letrozole which claims to lack these negative effects.

\section{AIM}

There are no studies authoritatively quantifying the effects of letrozole compared to clomiphene citrate, but Sammour and colleagues showed a higher pregnancy rate than clomiphene citrate ( $16.7 \%$ versus $5.6 \%$ per patient), i.e., more than three times higher pregnancy rates. ${ }^{31}$ Hence, in our study, we go ahead with the hypothesis that letrozole has at least $2.5 \%$ higher rates of ovulation induction and pregnancy than clomiphene citrate in view of its shorter half-life and consequent negligible antiestrogenic action on the endometrium and cervical mucus.

\section{OBJECTIVE}

To compare the efficacy of the aromatase inhibitor letrozole vs clomiphene citrate in controlled ovarian hyperstimulation $(\mathrm{COH})$-the parameters considered being: ovulation, pregnancy, and abortion rates, follicular size, number, and endometrial thickness. We also observed for the occurrence of multiple pregnancies, congenital anomalies, and ovarian hyperstimulation syndrome.

\section{REVIEW OF LITERATURE}

Stein and Levinthal ${ }^{32}$ in 1935 reported seven women who presented with problems of amenorrhoea, anovulation and bilateral enlarged polycystic ovaries with thickened tunica and were treated by wedge resection. Stein also reported 75 women who underwent wedge resection; $33.3490 \%$ of resumed regular menstruation and $65 \%$ became pregnant. ${ }^{35}$ The disease itself may be traced as far back as 1721 as an Italian printout which reads as: "Young married peasant women, moderately obese and infertile with two larger than normal ovaries, bumpy, shiny and whitish, just like pigeon eggs" (A Vallisneri). Similar ovarian changes were described by Chereau ${ }^{36}$ in 1844 .

Clomiphene citrate introduced in 1961, with around $70 \%$ ovulation and $30 \%$ pregnancy rates, ${ }^{37-39}$ began to be used for ovulation induction in women with PCOS. Greenbhatt ${ }^{24}$ report successful ovulation followed by pregnancy with this drug. Gonadotropins, ${ }^{40}$ selective estrogen receptor modulators, aromatase inhibitors are also used for ovulation induction. Surgery includes ovarian drilling and diathermy ${ }^{27}$ with $70-90 \%$ ovulation and $40-70 \%$ pregnancy rates. ${ }^{25}$ Medical induction is however favored due to fear of expenses and operative morbidity.

Letrozole is an aromatase inhibitor that prevents androgen to estrogen conversion. The antiestrogenic effects of clomiphene are not found with letrozole. $^{38,41-43}$

\section{DESCRIPTION OF DRUG}

\section{Clomiphene Citrate}

It inhibits the action of estrogen on the pituitary gland, competes with estrogen for estrogen-receptor-binding sites and delays replenishment of intracellular estrogen receptors. This results in increased release of FSH from the pituitary leading to a higher rate of ovulation and hence pregnancy. Dose: $100 \mathrm{mg}$ orally, once daily.

Treatment is usually commenced on day 2 of the cycle and given for 5 days. The starting dose of clomiphene is usually $50 \mathrm{mg}$. The dose should only be increased if there is no response after three cycles. All women who are prescribed clomiphene should be carefully monitored with an ultrasonographic assessment of follicular growth and ovulation because of the risk of multiple pregnancies.

Earlier reports had suggested an association between clomiphene and ovarian cancer with more than 12 months' therapy; although in most cases of prolonged use the indication was unexplained infertility rather than anovulation. ${ }^{44}$

\section{Side Effects}

Hot flushes, abdominal discomfort, visual blurring, and / or reversible ovarian enlargement and cyst formation, abnormal uterine bleeding, nausea, and/or vomiting. 


\section{Letrozone}

An oral nonsteroidal aromatase inhibitor45 that was used for the adjuvant treatment of hormonally-responsive breast cancer. Letrozole blocks the production of estrogens in this way by competitive, reversible binding to the heme of its cytochrome P450 unit. It does not downregulate the ER compared to CC46 and by lowering circulating estrogen releases hypothalamus from negative feedback of estrogen causing an increase in (gonadotropin-releasing hormone $(\mathrm{GnRH})$ which in turn leads to an increase in follicle stimulating hormone (FSH) and leutinizing hormone (LH). These stimulate the growth of ovarian follicles and increase the ovarian follicle sensitivity to FSH.

- Dose used: $2.5 \mathrm{mg}$ orally, bid

- Side effect: Nausea, vomiting, tiredness, headache, muscle aches, joint pains, hot flushes, hair thinning, vaginal dryness.

Letrozole inhibits estrogen synthesis, thereby causing enhanced GnRH pulsatility and consequent FSH and inhibin stimulation. This results in normal or enhanced follicular recruitment without the risk of multiple ovulation and OHSS. Letrozole has a very short half life ${ }^{46}$ and is quickly cleared from the body thus minimizing antioestrogenic effect on the endometrium and cervical mucus. Incidences of congenital anomalies have been found to be equal with both drugs. ${ }^{47}$

Mitwally and Casper reported the success of aromatase inhibition in inducing ovulation in women with PCOS. ${ }^{45,48}$ In another study, the same group reported the comparable success of an aromatase inhibitor in inducing ovulation in 12 women with PCOS in addition to success in augmenting ovulation in a group of 10 ovulatory women. Sammour et al. ${ }^{31}$ carried out a doubleblinded randomized trial that compared an aromatase inhibitor with clomiphene citrate for stimulation in 49 women with unexplained infertility where the patients receiving the aromatase inhibitor achieved a better uterine environment including increased blood flow as determined by Doppler ultrasound and increased endometrial thickness compared with that receiving clomiphene citrate. The aromatase inhibitor was associated with a higher pregnancy rate than clomiphene citrate $(16.7 \%$ vs. $5.6 \%$ per patient).

Mitwally and Casper also studied the benefits of using aromatase inhibitors along with gonadotrophins in ovulatory (unexplained infertility) and anovulatory PCOS women. ${ }^{49}$ This study concluded that cotreatment with an aromatase inhibitor significantly reduced the FSH dose ${ }^{49}$ required during controlled ovarian hyperstimulation as did clomiphene citrate. The aromatase inhibitor, however, was not associated with the antioestrogenic effects seen with clomiphene citrate treatment ${ }^{41,50}$ as demonstrated by the significantly lower endometrial thickness noted with clomiphene citrate treatment ${ }^{39}$ despite the significantly higher estradiol levels. ${ }^{51}$

\section{MATERIALS AND METHODS}

This study was carried out in the Department of Obstetrics and Gynecology, Kerala Institute of Medical Sciences. This hospital is a privately run tertiary referral center and teaching hospital, which serves the districts of Trivandrum, Kollam, Pathanamthitta in Kerala and Kanyakumari and Tirunelveli districts of Tamil Nadu.

Our study was a prospective randomized controlled trial. The randomization unit was the individual drug and the schedule of allotment of the drug to each patient was determined by computer-generated random numbers. The drug to be prescribed was placed in sealed envelopes along with the mode of consuming the same. The doctor was not aware of the drug prescribed, but the patient was aware of the same, with clomiphene having once daily and letrozole twice daily dosage schedule. The analysis was performed by an independent analyzer.

\section{Inclusion Criteria}

- All patients satisfying criteria for PCOS according to the Rotterdam criteria. ${ }^{14,15}$

- Seeking treatment for infertility.

- Willing to participate in the study.

\section{Exclusion Criteria}

- Women with hyperthyroidism/hyperprolactinemia/ pituitary causes of infertility.

- Pregnancy.

- Male factor abnormalities

- Women with a tubal block: This was ruled out with hysterosalpingography. Some doctors recommend a laparoscopy to exclude tubal blockage before the commencement of treatment.

Another approach, in the absence of any symptoms or signs of pelvic disease, is to undertake treatment and only perform laparoscopy if pregnancy has not occurred after six months of treatment. This approach had to be taken in our study in view of the unwillingness of most patients to attempt any surgical modality before the use of medications.

\section{SAMPLING PROCEDURE}

In our study, we go ahead with the hypothesis that Letrozole has at least $2.5 \%$ higher rates of ovulation induction and pregnancy than clomiphene citrate. ${ }^{31}$ Hence, we arrived at the sample size with the help of the following formula: 
$\mathrm{N}=\frac{\left[Z_{\alpha} \sqrt{2} \bar{p} \bar{q}+Z_{\beta} \sqrt{p_{1} q_{1}+p_{0} q_{0}}\right]^{2}}{\left(p_{1}-p_{0}\right)^{2}}$

where $=P_{1}=\frac{P_{0 R}}{1+p_{0}(R-1)}$

$\bar{q}=1-\overline{\bar{p}}=\frac{1}{2}\left(p_{1+p_{\mathrm{n}}}\right)$

$\mathrm{q} 1=1-p_{1}$

$q_{0}=1-$

$\mathrm{P}_{0}=$ Percentage of pregnancies usually achieved with clomiphene citrate $=40 \%$ with an ovulation rate of $80 \%$

$\therefore=0.40$

$\mathrm{R}=2.5$ (Letrozole hypothesized to have 2.5 times higher pregnancy rate than clomiphene)

$\mathrm{Z} \alpha=1.96$ for $\alpha=0.05$

$\mathrm{Z} \beta=1.28$ for $\beta=90 \%$ power

$\therefore \mathrm{N}=101 \approx 100$ women in each group

A sample of 200 consecutive women was taken (after block randomization), assigned to two groups. Group 0 - Clomiphene citrate -96 patients and group 1-Letrozole-104 patients.

The period of study decided upon was 1 year 6 months from July 2008 to February 2010. This was preceded by 3 months of treatment with metformin, exercise, lifestyle modification, and folic acid.

\section{CONDUCT OF STUDY}

- A thorough history was taken to rule out other causes of anovulation and infertility including galactorrhea, symptoms suggestive of thyroid hormone abnormalities, features suggestive of hyperandrogenism, hyperinsulinemia, etc.

- Complete medical and gynecological examination including complete blood count, liver, thyroid and renal function tests, prolactin, $\mathrm{FSH} / \mathrm{LH}$, Testosterone, and DHEAS.

- Baseline transvaginal ultrasonogram (TVS) to assess features of polycystic ovaries was done prior to the commencement of treatment.

\section{PROCEDURE}

A sample of 200 consecutive women (after block randomization) was assigned to participate in the study after counseling and obtaining informed consent. Polycystic ovary syndrome was defined as per Rotterdam criteria. Withdrawal bleeding was achieved with $10 \mathrm{mg}$ levonorgestrel tablets for five days before stimulation. Group 0 were subjected to ovulation induction with $100 \mathrm{mg}$ OD of clomiphene citrate and group 1 with $2.5 \mathrm{~m}$ of letrozole $\mathrm{BD}$ for five days starting on day 3 of menses.

Follicular monitoring was done by TVS on days 10,12, 14,16 of the cycle till a mature follicle of size $1.4-1.8 \mathrm{~cm}$ or more (by averaging inner two diameters of the follicle) was detected. A single injection of hCG 10,000 IU IM was given if at least one follicle was $>14 \mathrm{~mm}$ and the endometrial thickness at least more than $8 \mathrm{~cm}$. A second TVS was done after 48 hours of hCG to observe the release of the egg. If the follicle was found unruptured, a third TVS was done after 72 hours of the hCG injection to observe a luteinized unruptured follicle.

Ovulation was ascertained by observing rupture of the follicle by TVS-collapsed follicle, fluid in the pouch of Douglas. Endometrial thickness was measured in the plane through the central longitudinal axis of the uterus at a point of maximum distance between the echogenic interfaces of the diameter. A trilaminar diameter of $\geq 8$ $\mathrm{mm}$ was considered a satisfactory response.

Timed intercourse was advised 36 hours after hCG on two consecutive days and the luteal phase was supplemented with micronized progesterone/dydrogesterone. The main outcome measure considered was the rate of ovulation and pregnancy. Three to four cycles were observed for pregnancy.

If follicular development was poor, the cycle was canceled. If the cycle was canceled, and another cycle to be started, the protocol was followed again from step 1 above.

\section{OUTCOME VARIABLES/MEASURES}

Both groups were compared with regard to:

- Successful follicular maturation (14-18 mm).

- Failure of follicular maturation.

- A number of follicles recruited per cycle with each drug.

- Endometrial thickness in each cycle-prior to and after hCG injection.

- Number of cycles following which pregnancy occurred.

- Rate of pregnancy and miscarriage.

- Rate of multiple pregnancies.

- Side effects like OHSS if any.

\section{DATA ENTRY AND ANALYSIS}

Using Microsoft excel sheet and analysis by SPSS package.

\section{Ethical Issues}

These were tackled by the institutional and local ethical committee. The study commenced after obtaining complete informed consent from the patients.

\section{Analysis of Data}

The descriptive statistics-mean, median, standard deviation, percentages were used to summarize the findings. The difference between the two groups was tested by t-test in case of continuous variables and Chi-square test in case of categorical data. 
A $p$ value of $\leq 0.05$ was considered significant. Results were expressed as the mean and standard error of deviation.

\section{LIMITATION OF STUDY}

Laparoscopic evaluation of tubal factor was not found to be feasible in every case in view of the cost factor and the limited time of the study. Some patients were lost to follow-up.

Estimation of serum estradiol and progesterone could not be done in view of the additional expenditure for the patients.

The study was not double-blinded, in that the patient was aware of the drug which she was taking.

\section{OBSERVATIONS AND RESULTS}

- Age: Of the total population studied, 31\% were less than or equal to 24 years of age; $49 \%$ between $25-29$ years of age and $20 \%$ more than or equal to 30 years (Table 1 and Graph 1). It was noted that (Table 2 and Graph 2) in the clomiphene group 28.1\% were below or equal to 24 years of age, 53.1\% between 25 years and 29 years and $18.8 \%$ more than or equal to 30 years of age. In the letrozole group $33.7 \%$ were less than or equal to 24 years of age, $45.2 \%$ between 25 years and 29 years and $21.2 \%$ more than or equal to 30 years of age. The $p$ value was 0.822 hence no significant difference in the age distribution of patients in either group.

Table 1: Percentage distribution of the sample according to age

\begin{tabular}{lll}
\hline Age & Count & Percent \\
\hline$\leq 24$ & 62 & 31.0 \\
$25-29$ & 98 & 49.0 \\
$\geq 30$ & 40 & 20.0 \\
\hline Total & 200 & \\
\hline Mean \pm SD & $26.7 \pm 4.1$ &
\end{tabular}

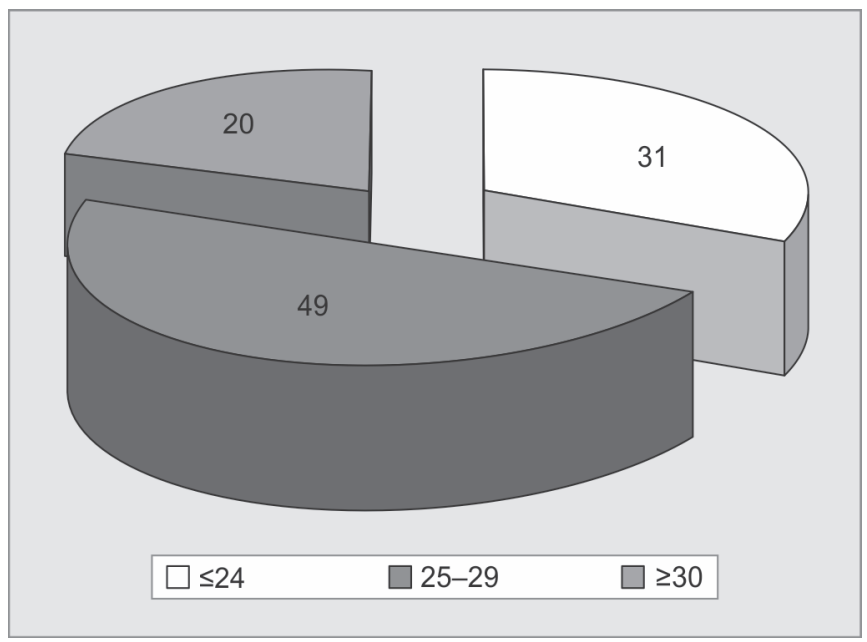

Graph 1: Percent distribution of the sample according to age
- Duration of married life: Forty percent of patients were at or past 2 years of married life at the commencement of treatment (Table 3 and Graph 3), 23.5\% between 2 years and 4 years, $17.5 \%$ between 4 years and 6 years and $19.0 \%$ more than 6 years of married life (Table 4 and Graph 4). It was noted that in clomiphene group the duration of marital life prior to commencement of the study was less than or equal to 2 years in $39.6 \%$, between 2 years and 4 years in $21.9 \%$, between 4 years and 6 years in $17.7 \%$, more than or equal to 6 in $20.8 \%$ with a mean \pm standard deviation of $4.1 \pm 2.7$ compared to $40.4 \%, 25 \%, 17.3 \%, 17.3 \%$, respectively in letrozole group with a mean \pm standard deviation of $4.1+3.2$. The $p$ value was 0.984 , hence no significant difference in the distribution between the two groups.

- Parity: Nearly $61.5 \%$ of patients had primary infertility, $30.5 \%$ had at least 1 previous pregnancy and $8.0 \%$ had 2 previous pregnancies (Table 5 and Graph 5). The percentages of distribution of primary infertility, secondary infertility with one previous pregnancy, two previous pregnancies were $65.6 \%, 25 \%, 9.4 \%$ respectively in clomiphene group compared to $57.7 \%$, $35.6 \%$, and $6.7 \%$, respectively in the letrozole group (Table 6 and Graph 6). The $p$ value was 0.249 hence no significant difference in the distribution of patients between the two groups.

- Menstrual pattern: The percentage of women with regular and irregular menstrual cycles was found to be $12.5 \%$ and $87.5 \%$, respectively in the clomiphene

Table 2: Percentage distribution of the sample

\begin{tabular}{lll}
\hline Duration of married life & Count & Percent \\
\hline$\leq 2$ & 80 & 40.0 \\
$2-4$ & 47 & 23.5 \\
$4-6$ & 35 & 17.5 \\
\hline$>6$ & 38 & 19.0 \\
\hline Mean \pm SD & $4.1 \pm 3$ &
\end{tabular}

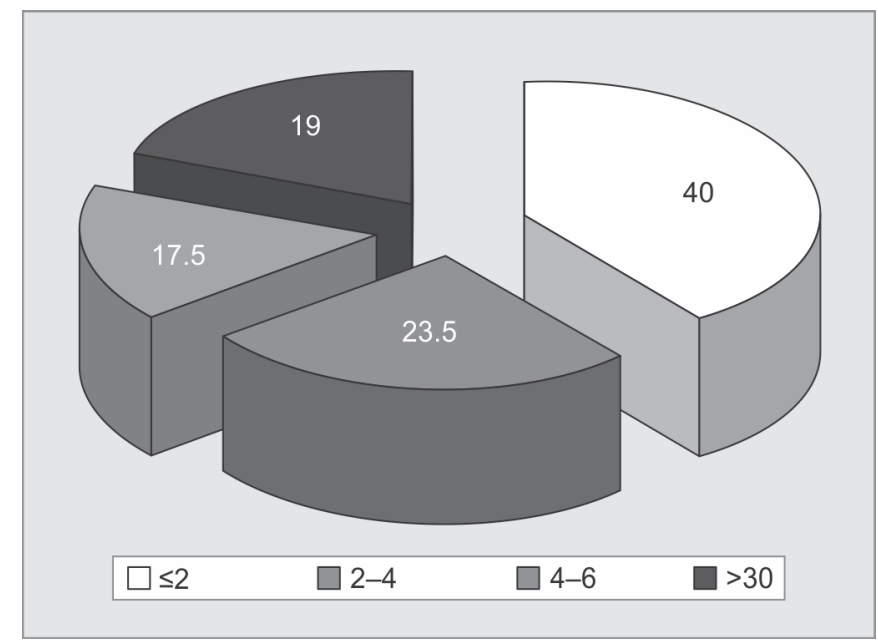

Graph 2: Percent distribution of the sample of duration of married life age 
group compared to $14.4 \%$ and $85.6 \%$, respectively in the letrozole group. The $p$ value was 0.691 , again showing comparable distribution of patients between the two groups (Table 7 and Graph 7).

Table 3: Percent distribution of the sample according to parity

\begin{tabular}{lll}
\hline Parity & Count & Percent \\
\hline 0 & 123 & 61.5 \\
1 & 61 & 30.5 \\
2 & 16 & 8.0 \\
\hline
\end{tabular}

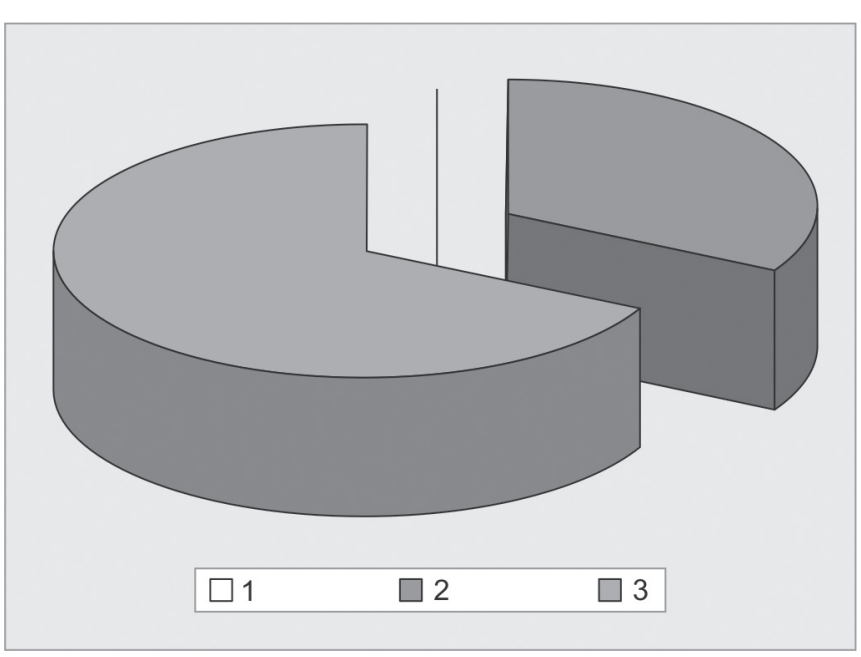

Graph 3: Percent distribution of the sample according to parity

Table 5: Comparison of Duration of married life based on drug

\begin{tabular}{lllll}
\hline & \multicolumn{4}{c}{ Drug } \\
\cline { 2 - 5 } $\begin{array}{l}\text { Duration of } \\
\text { married life }\end{array}$ & Clomiphene & \multicolumn{3}{c}{ Letrozole } \\
\cline { 2 - 5 }$\leq 2$ & 38 & 39.6 & 42 & 40.4 \\
$2-4$ & 21 & 21.9 & 26 & 25.0 \\
$4-6$ & 17 & 17.7 & 18 & 17.3 \\
$>6$ & 20 & 20.8 & 18 & 17.3 \\
Mean \pm SD & $4.1 \pm 2.7$ & & $4.1 \pm 3.2$ \\
\hline $\mathrm{t}=0.02$ & $p=0.984$ & & &
\end{tabular}

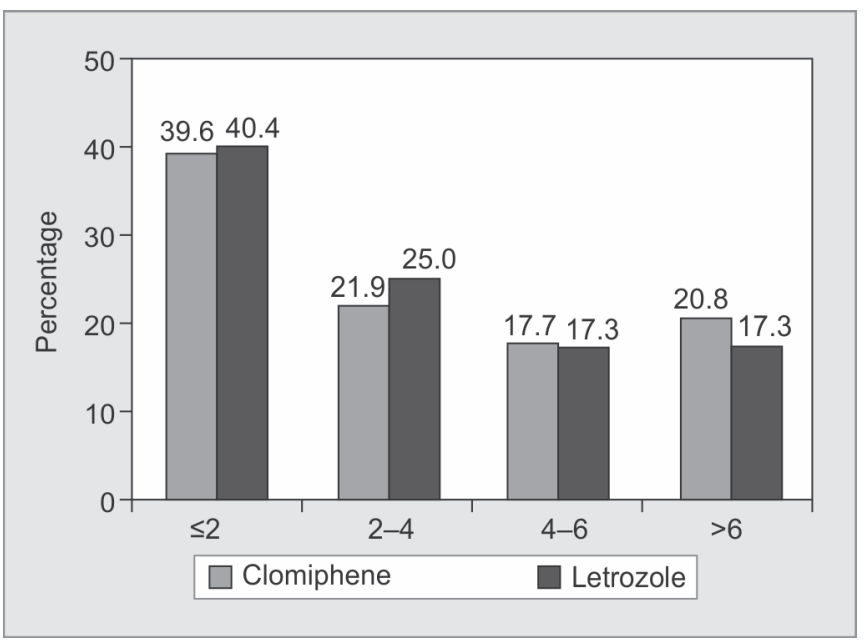

Graph 5: Comparison of duration of married life based on drug

\section{HISTORY OF OVULATION INDUCTION}

In the clomiphene group, (Table 8 and Graph 8) 64.6\% of patients had a prior history of ovulation induction

Table 4: Comparison of age based on drug

\begin{tabular}{lllll}
\hline & \multicolumn{4}{c}{ Drug } \\
\cline { 2 - 5 } Age & Clomiphene & \multicolumn{3}{c}{ Letrozole } \\
\cline { 2 - 5 } & Count & Percent & Count & Percent \\
\hline$\leq 24$ & 27 & 28.1 & 35 & 33.7 \\
$25-29$ & 51 & 53.1 & 47 & 45.2 \\
$\geq 30$ & 18 & 18.8 & 22 & 21.2 \\
Mean \pm SD & $26.8 \pm 3.9$ & & $26.7 \pm 4.3$ & \\
\hline
\end{tabular}

$\mathrm{t}=0.22 p=0.822$

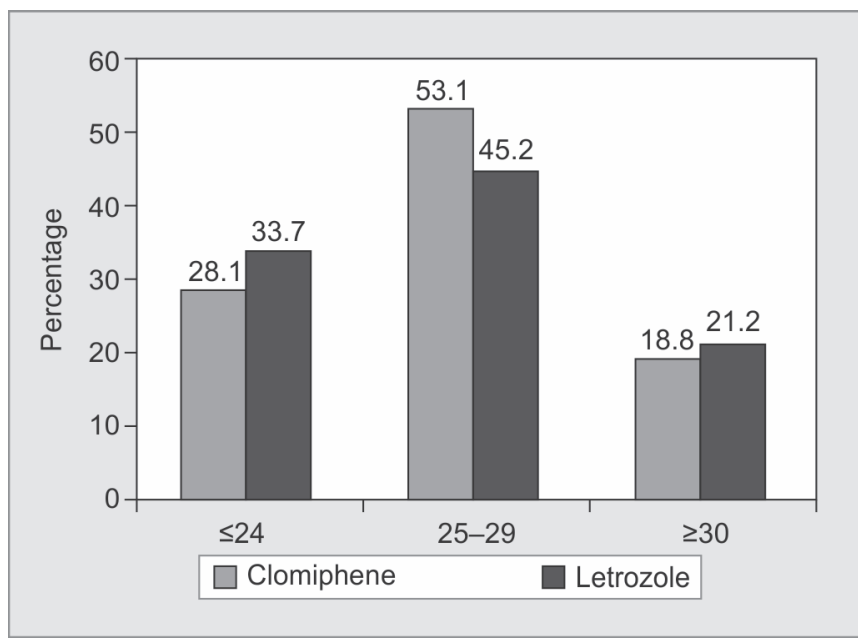

Graph 4: Comparison of age based on drug

Table 6: Comparison of parity based on drug

\begin{tabular}{lllllll}
\hline & \multicolumn{5}{c}{ Drug } & \\
\cline { 2 - 5 } & \multicolumn{3}{c}{ Clomiphene } & \multicolumn{2}{c}{ Letrozole } & \\
\cline { 2 - 6 } Parity & Count & Percent & Count & Percent & $x^{2}$ & $p$ \\
\hline 0 & 63 & 65.6 & 60 & 57.7 & 2.78 & 0.249 \\
1 & 24 & 25.0 & 37 & 35.6 & & \\
2 & 9 & 9.4 & 7 & 6.7 & & \\
\hline
\end{tabular}

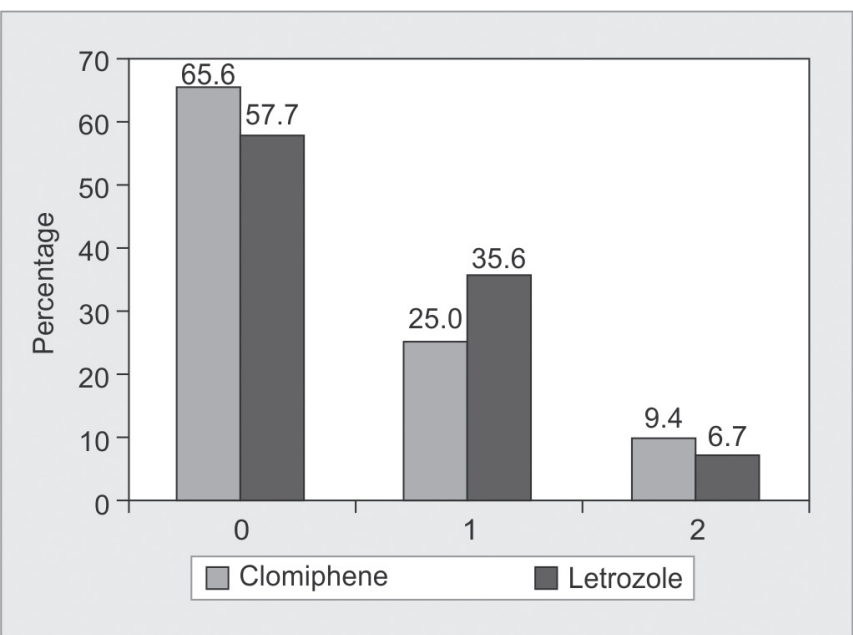

Graph 6: Comparison of parity based on drug 
compared to $55.8 \%$ in the letrozole group. The $p$ value was 0.204 showing no significant difference between the two groups.

\section{History of Laparoscopy}

In the clomiphene group, (Table 9 and Graph 9) 30.2\% of patients had a prior history of having undergone lapa-

Table 7: Comparison of type of menstruation based on drug

\begin{tabular}{|c|c|c|c|c|c|c|}
\hline \multirow{3}{*}{$\begin{array}{l}\text { Type of } \\
\text { menstruation }\end{array}$} & \multicolumn{4}{|c|}{ Drug } & \multirow[b]{3}{*}{$\chi^{2}$} & \multirow[b]{3}{*}{$p$} \\
\hline & \multicolumn{2}{|c|}{ Clomiphene } & \multicolumn{2}{|c|}{ Letrozole } & & \\
\hline & Count & Percent & Count & Percent & & \\
\hline Regular & 12 & 12.5 & 15 & 14.4 & 016 & 0 \\
\hline Irregular & 84 & 87.5 & 89 & 85.6 & & 1 \\
\hline
\end{tabular}

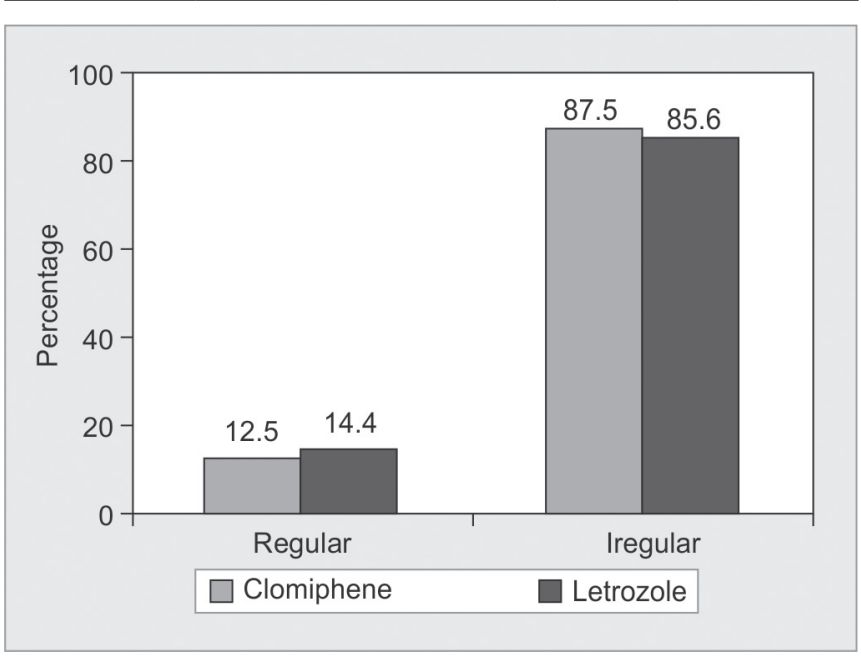

Graph 7: Comparison of type of menstruation based on drug

Table 8: Comparison of history of ovulation induction based on drug

\begin{tabular}{|c|c|c|c|c|c|c|}
\hline \multirow{3}{*}{$\begin{array}{l}\text { History of } \\
\text { Ovulation } \\
\text { induction }\end{array}$} & \multicolumn{4}{|c|}{ Drug } & \multirow[b]{3}{*}{$\chi^{2}$} & \multirow[b]{3}{*}{$p$} \\
\hline & \multicolumn{2}{|c|}{ Clomiphene } & \multicolumn{2}{|c|}{ Letrozole } & & \\
\hline & Count & Percent & Count & Percent & & \\
\hline No & 34 & 35.4 & 46 & 44.2 & 1.62 & 0.204 \\
\hline Yes & 62 & 64.6 & 58 & 55.8 & & \\
\hline
\end{tabular}

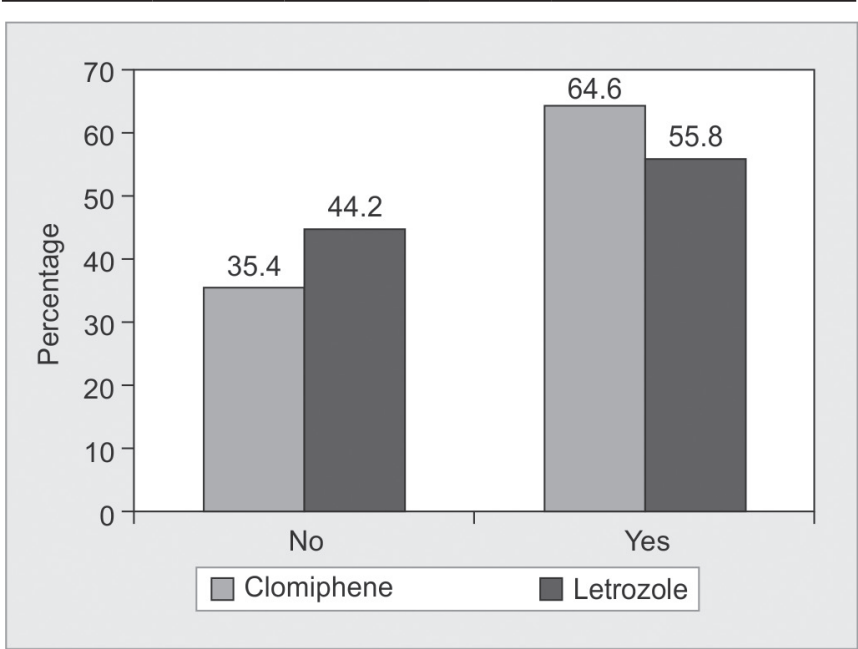

Graph 8: Comparison of history of ovulation induction based on drug roscopy as part of infertility workup compared to $23.1 \%$ in the letrozole group. The $p$ value of 0.254 showed no significant difference in the distribution of patients in the two groups.

\section{History of Intrauterine Insemination}

About $40.6 \%$ of patients (Table 10 and Graph 10) belonging to the clomiphene group had a history of having undergone IUI compared to $30.8 \%$ in the letrozole group, with a $p$ value of 0.146 with no statistically significant difference between the two groups.

\section{Body Mass Index}

The percentage of patients (Table 11 and Graph 11) with BMI between 19 and 24.9;25-29.9 and more than or equal to 30 was found to be $42.7 \%, 41.75$ and $15.6 \%$, respectively in the clomiphene group when compared to $41.35,41.3 \%$ and $17.3 \%$, respectively in the letrozole group. The $p$ value was 0.198 showing no statistically significant difference between the two groups.

\section{Hyperandrogenism}

In the clomiphene group, (Table 12 and Graph 12) 81.3\% of patients showed evidence of hyperandrogenism (in the form of acne, hirsutism) compared to $85.6 \%$ of patients in the letrozole group. The $p$ value was 0.410 which was again not significant.

Table 9: Comparison of laparoscopy based on drug

\begin{tabular}{|c|c|c|c|c|c|c|}
\hline \multirow[t]{3}{*}{ Laparoscopy } & \multicolumn{4}{|c|}{ Drug } & \multirow[b]{3}{*}{$\chi^{2}$} & \multirow[b]{3}{*}{$p$} \\
\hline & \multicolumn{2}{|c|}{ Clomiphene } & \multicolumn{2}{|c|}{ Letrozole } & & \\
\hline & Count & Percent & Count & Percent & & \\
\hline No & 67 & 69.8 & 80 & 76.9 & \multirow{2}{*}{1.3} & \multirow{2}{*}{0.254} \\
\hline Yes & 29 & 30.2 & 24 & 23.1 & & \\
\hline
\end{tabular}

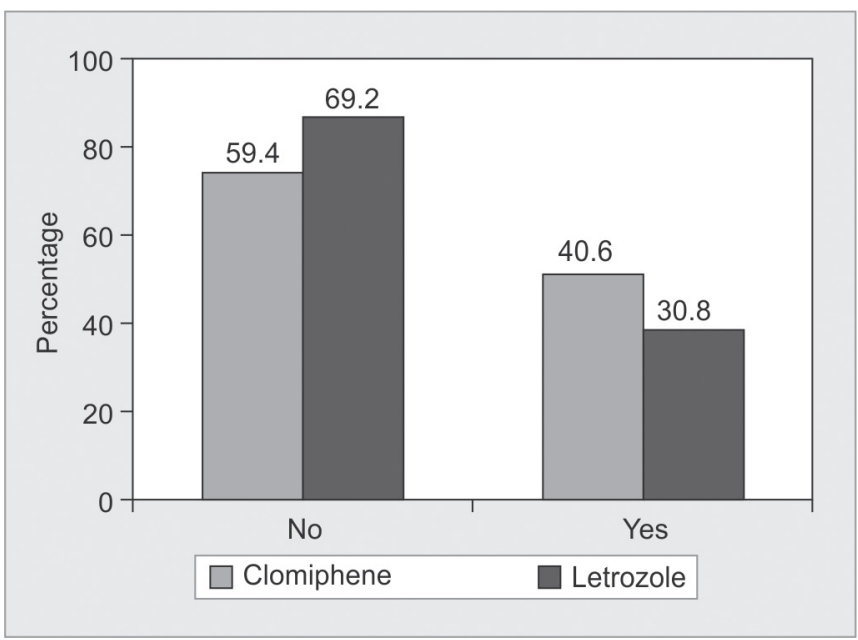

Graph 9: Comparison of laparoscopy based on drug 


\section{ULTRASOUND FEATURES}

About $84.4 \%$ of patients (Table 13 and Graph 13) in the clomiphene group had ultrasonologically defined polycystic ovaries as compared to $80.8 \%$ in the letrozole group. The $p$ value was 0.503 , not statistically significant.

Table 10: Comparison of IUI based on drug

\begin{tabular}{|c|c|c|c|c|c|c|}
\hline \multirow[b]{3}{*}{$I U I$} & \multicolumn{4}{|c|}{ Drug } & \multirow[b]{3}{*}{$\chi^{2}$} & \multirow[b]{3}{*}{$p$} \\
\hline & \multicolumn{2}{|c|}{ Clomiphene } & \multicolumn{2}{|c|}{ Letrozole } & & \\
\hline & Count & Percent & Count & Percent & & \\
\hline No & 57 & 59.4 & 72 & 69.2 & 2.12 & 0.146 \\
\hline Yes & 39 & 40.6 & 32 & 30.8 & & \\
\hline
\end{tabular}

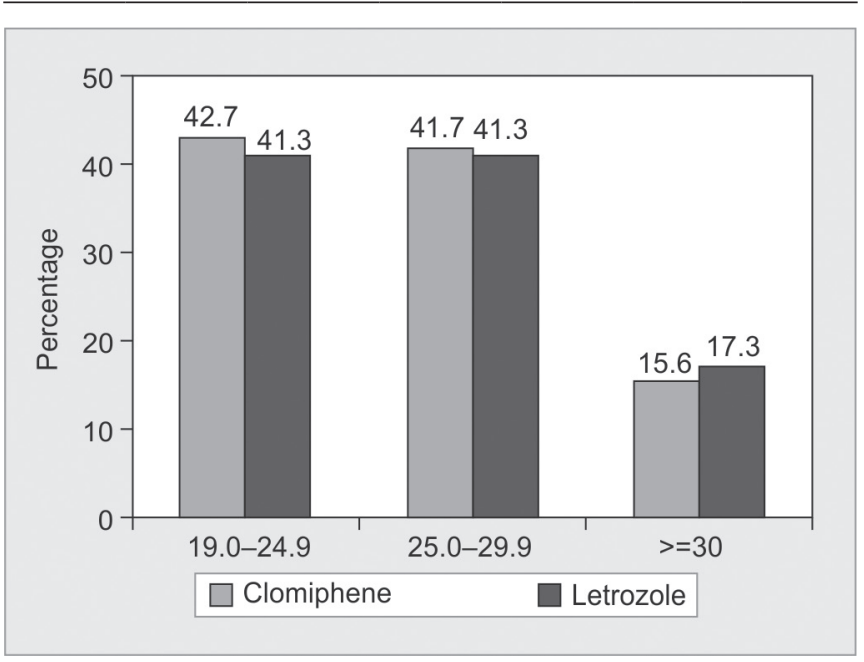

Graph 10: Comparison of IUI based on drug

Table 11: Comparison of BMI based on drug

\begin{tabular}{lllll}
\hline & \multicolumn{4}{c}{ Drug } \\
\cline { 2 - 5 } BMI & \multicolumn{3}{c}{ Clomiphene } & \multicolumn{2}{c}{ Letrozole } \\
\cline { 2 - 5 } & Count & Percent & Count & Percent \\
\hline $19.0-24.9$ & 41 & 42.7 & 43 & 41.3 \\
$25.0-29.9$ & 40 & 41.7 & 43 & 41.3 \\
$\geq 30$ & 15 & 15.6 & 18 & 17.3 \\
Mean \pm SD & & $25.6 \pm 3.6$ & & $26.3 \pm 4$ \\
\hline
\end{tabular}

$\mathrm{t}=1.28, p=0.198$

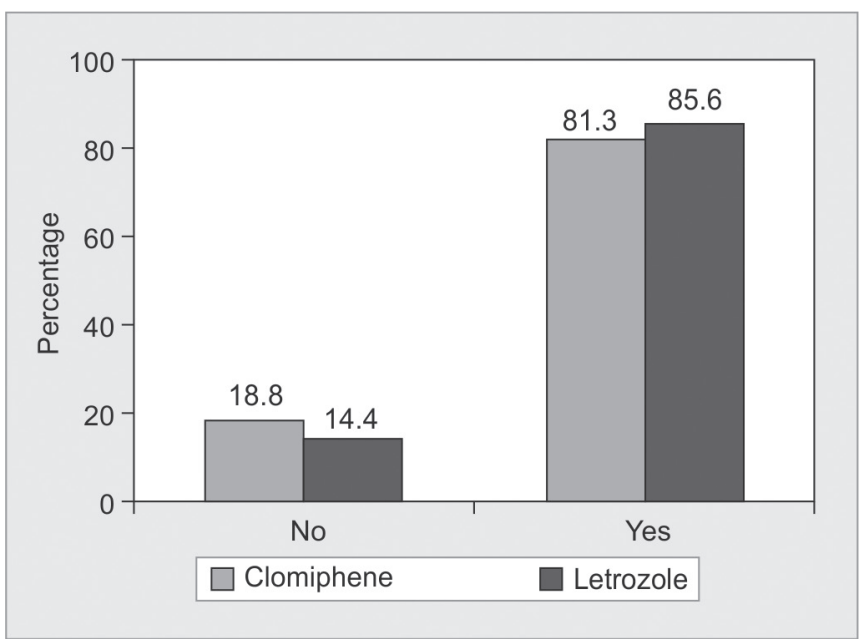

Graph 11: Comparison of BMI based on drug

\section{LABORATORY FINDINGS}

About 27.1\% patients (Table 14 and Graph 14) in the clomiphene group had laboratory findings suggestive of hyperandrogenism compared to $39.4 \%$ in the letrozole group with a statistically insignificant $p$ value of 0.065 .

\section{Number of Cycles In Which Pregnancy was Achieved}

In the clomiphene group, (Table 15 and Graph 15) 30.2\% patients achieved pregnancy in 1-2 cycles, $62.55 \%$ in 3-4 cycles and $7.3 \%$ in 5-6 cycles with a mean \pm standard deviation of $3+1.01$ when compared to $30.8 \%, 66.3 \%$ and $2.9 \%$ respectively in the letrozole group with a mean \pm standard deviation of $2.92 \pm 0.89$. The $p$ value was 0.566 , again not statistically significant.

\section{Follicle Size More than or Equal to $14 \mathrm{~mm}$}

When compared for the total number of follicles more than or equal to $14 \mathrm{~mm}$ seen in the clomiphene group, (Table 16 and Graph 16) a mean \pm standard deviation of $2.54 \pm 0.77$ was seen comparedto $1.39 \pm 0.53$ in the letrozole group. This had a $p$ value of $<0.01$, hence statistically significant. The clomiphene group had a statistically significant increase in the total number of follicles more than or equal to $14 \mathrm{~mm}$, i.e., significant multifollicular development.

\section{Monofollicular Development More than or Equal to $14 \mathrm{~mm}$}

About $60.2 \%$ of patients (Table 17 and Graph 17) in the letrozole group showed monofollicular development

Table12: Comparison of Hyperandrogenism based on drug

\begin{tabular}{|c|c|c|c|c|c|c|}
\hline \multirow{3}{*}{$\begin{array}{l}\text { Hyperandro- } \\
\text { genism }\end{array}$} & \multicolumn{4}{|c|}{ Drug } & \multirow[b]{3}{*}{$x^{2}$} & \multirow[b]{3}{*}{$p$} \\
\hline & \multicolumn{2}{|c|}{ Clomiphene } & \multicolumn{2}{|c|}{ Letrozole } & & \\
\hline & Count & Percent & Count & Percent & & \\
\hline No & 18 & 18.8 & 15 & 14.4 & 0.68 & 0.410 \\
\hline Yes & 78 & 81.3 & 89 & 85.6 & & \\
\hline
\end{tabular}

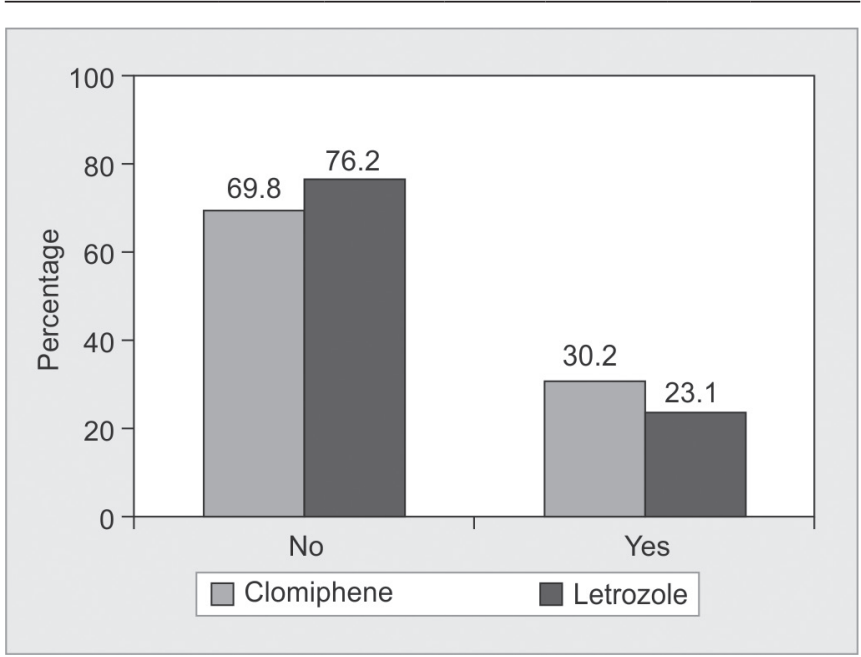

Graph 12: Comparison of hyperandrogenism based on drug 


\begin{tabular}{lllllll}
\multicolumn{7}{c}{ Table 13: Comparison of USS based on drug } \\
\cline { 2 - 6 } & \multicolumn{7}{c}{ Drug } \\
\cline { 2 - 6 } USS & Count & Percent & Count & Percent & $x^{2}$ & $p$ \\
\hline No & 15 & 15.6 & 20 & 19.2 & 0.45 & 0.503 \\
Yes & 81 & 84.4 & 84 & 80.8 & & \\
\hline
\end{tabular}

Table 14: Comparison of laboratory test abnormalities based on

\begin{tabular}{|c|c|c|c|c|c|c|}
\hline \multirow{3}{*}{$\begin{array}{l}\text { Laboratory } \\
\text { test } \\
\text { abnormalities }\end{array}$} & \multicolumn{4}{|c|}{ Drug } & \multirow[b]{3}{*}{$x^{2}$} & \multirow[b]{3}{*}{$p$} \\
\hline & \multicolumn{2}{|c|}{ Clomiphene } & \multicolumn{2}{|c|}{ Letrozole } & & \\
\hline & Count & Percent & Count & Percent & & \\
\hline No & 70 & 72.9 & 63 & 60.6 & 3.41 & 0.065 \\
\hline Yes & 26 & 27.1 & 41 & 39.4 & & \\
\hline
\end{tabular}

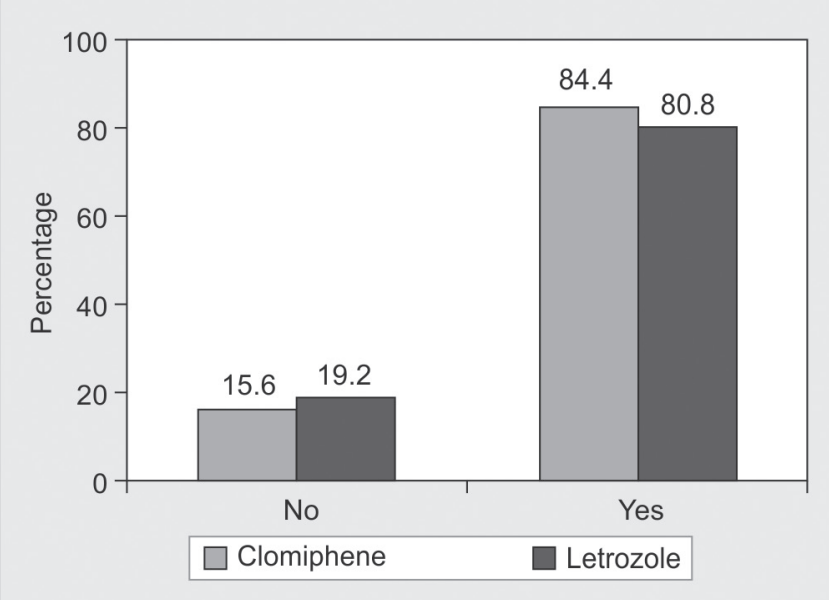

Graph 13: Comparison of USS based on drugage

Table15: Comparison of number of cycles based on drug

\begin{tabular}{lllll}
\hline & \multicolumn{4}{c}{ Drug } \\
\cline { 2 - 5 } $\begin{array}{l}\text { Number of } \\
\text { cycles }\end{array}$ & \multicolumn{3}{c}{ Clomiphene } & \multicolumn{3}{c}{ Letrozole } \\
\cline { 2 - 5 } & Count & Percent & Count & Percent \\
\hline $1-2$ & 29 & 30.2 & 32 & 30.8 \\
$3-4$ & 60 & 62.5 & 69 & 66.3 \\
$5-6$ & 7 & 7.3 & 3 & 2.9 \\
Mean \pm SD & $3 \pm 1.01$ & & $2.92 \pm 0.89$ \\
\hline
\end{tabular}

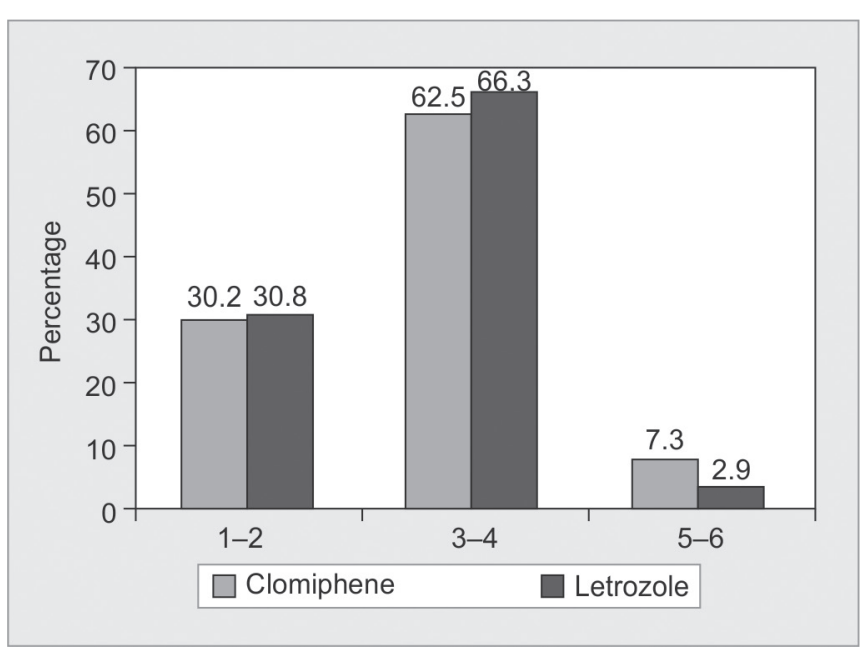

Graph 15: Comparison of number of cycles based on drug

compared to only $9.4 \%$ in the clomiphene group; whereas multifollicular development was seen in $90.6 \%$ patients in the clomiphene group compared to $39.8 \%$ of the letrozole group. The $p$ value was 0.000 . Hence, monofollicular development was found to be very highly statistically significant in the letrozole group, which is one of its major advantages.

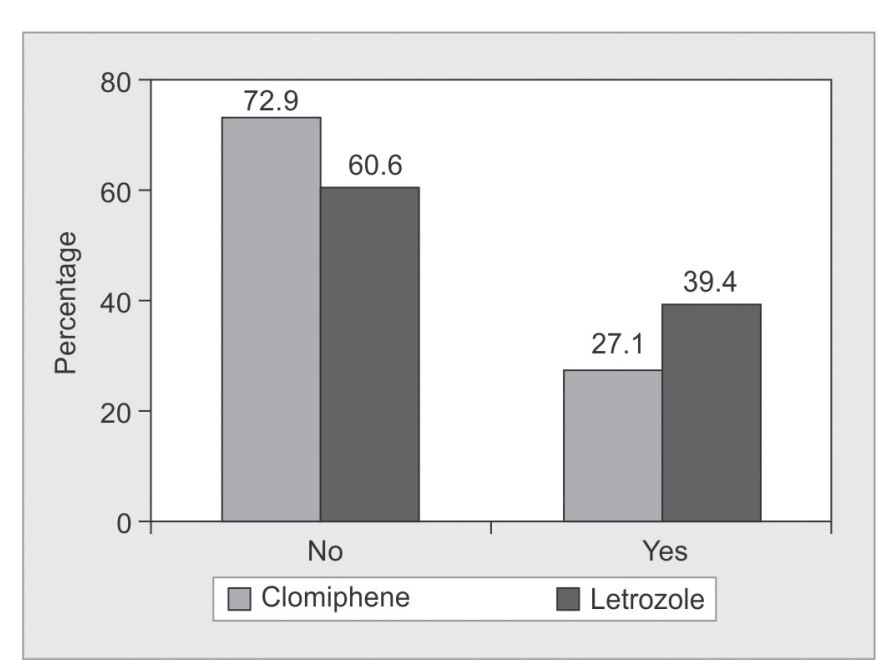

Graph 14: Comparison of lab test based on drug

Table 16: Comparison of number of follicles $>14 \mathrm{~mm}$ based on drug

\begin{tabular}{lllll}
\hline \multirow{2}{*}{$\begin{array}{l}\text { Number } \\
\text { follicle }>14 \\
m m\end{array}$} & \multicolumn{4}{c}{ Clomiphene } \\
\cline { 2 - 5 } & Count & Percent & Count & Percent \\
\hline 0 & 0 & 0.0 & 1 & 1.0 \\
1 & 9 & 9.4 & 62 & 59.6 \\
2 & 33 & 34.4 & 40 & 38.5 \\
3 & 47 & 49.0 & 1 & 1.0 \\
4 & 7 & 7.3 & 0 & 0.0 \\
Mean \pm SD & & $2.54 \pm 0.77$ & & $1.39 \pm 0.53$ \\
\hline $\mathrm{t}=12.4, p<0.01$ & & &
\end{tabular}

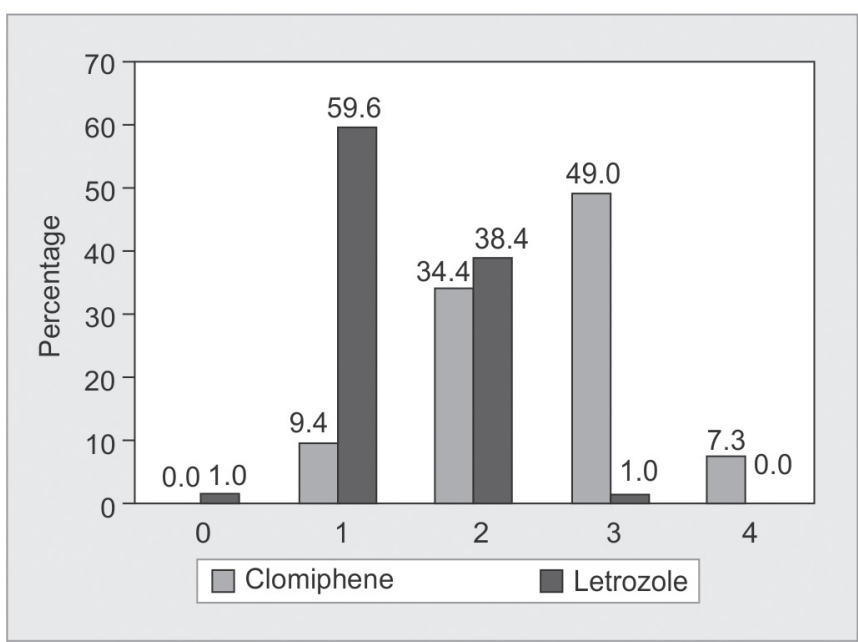

Graph 16: Comparison of number of follicles $>14 \mathrm{~mm}$ based on drug 
Table 17: Comparison of follicle $>14 \mathrm{~mm}$ based on drug

\begin{tabular}{lllllll}
\hline \multirow{2}{*}{$\begin{array}{l}\text { Number } \\
\text { follicle } \\
>14\end{array}$} & \multicolumn{5}{c}{ Clomiphene } & \multicolumn{3}{c}{ Letrozole } & & \\
\cline { 2 - 5 }$m$ mm & Count & Percent & Count & Percent & $\chi^{2}$ & $p$ \\
\hline Single & 9 & 9.4 & 62 & 60.2 & $55.9^{* *}$ & 0.000 \\
Multiple & 87 & 90.6 & 41 & 39.8 & & \\
\hline
\end{tabular}

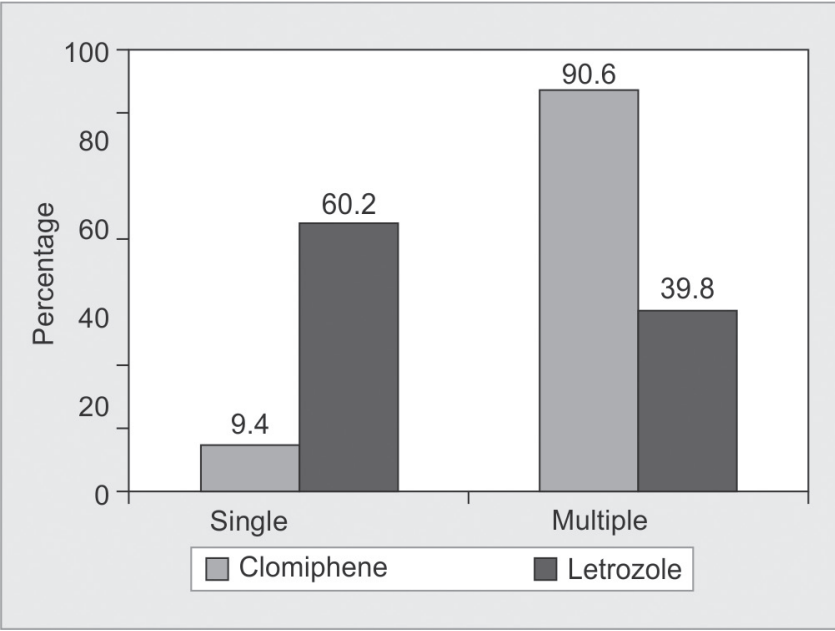

Graph 17: Comparison of follicle $>14 \mathrm{~mm}$ based on drug

\section{Follicle Size More than or Equal to $18 \mathrm{~mm}$}

When compared for the total number of follicles (Table 18 and Graph 18) more than or equal to $18 \mathrm{~mm}$ seen in the clomiphene group, a mean \pm standard deviation of $1.4 \pm$ 0.7 was seen compared to $1.06 \pm 0.6$ in the letrozole group. This had a $p$ value of $<0.01$, hence statistically significant. The clomiphene group had a statistically significant increase in the total number of follicles more than or equal to $18 \mathrm{~mm}$, i.e., significant multifollicular development.

\section{Monofollicular Development More than or Equal to $18 \mathrm{~mm}$}

Eighty percent of patients (Table 19 and Graph 19) in the letrozole group showed monofollicular development compared to only $53.9 \%$ in the clomiphene group; whereas multifollicular development was seen in $46.1 \%$ patients in the clomiphene group compared to $20 \%$ of the letrozole group. The $p$ value was 0.000 . Hence monofollicular development was found to be very highly statistically significant in the letrozole group, which is one of its major advantages.

\section{Size of Dominant Follicle}

In the clomiphene citrate group, (Table 20 and Graph 20) the size of the dominant follicle was more than $15 \mathrm{~mm}$ in $13.5 \%$, between 15 and $19.9 \mathrm{~mm}$ in $47.9 \%$ and between 20 and $24.9 \mathrm{~mm}$ in $33.3 \%$ of the patients. In the letrozole group the corresponding values were $11.5 \%, 39.4 \%$ and
Table 18: Comparison of number follicle $\geq 18 \mathrm{~mm}$ based on drug

\begin{tabular}{lllll}
\hline & \multicolumn{4}{c}{ Drug } \\
\cline { 2 - 5 } $\begin{array}{l}\text { Number follicle } \\
>18 \mathrm{~mm}\end{array}$ & \multicolumn{2}{c}{ Clomiphene } & \multicolumn{2}{c}{ Letrozole } \\
\cline { 2 - 5 } & Count & Percent & Count & Percent \\
\hline 0 & 7 & 7.3 & 14 & 13.5 \\
1 & 48 & 50.0 & 72 & 69.2 \\
2 & 38 & 39.6 & 16 & 15.4 \\
3 & 3 & 3.1 & 2 & 1.9 \\
Mean \pm SD & & $1.4 \pm 0.7$ & & $1.06 \pm 0.6$ \\
\hline $\mathrm{t}=3.63^{* *} p<0.01$ & & & &
\end{tabular}

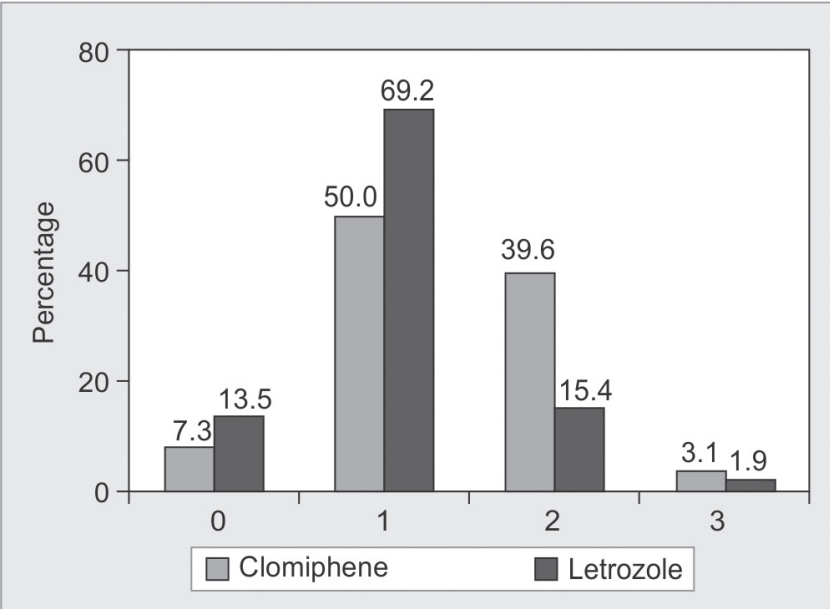

Graph 18: Comparison of number follicle $\geq 18 \mathrm{~mm}$ based on drug

$45.2 \%$ respectively. The mean size of the dominant follicle was $18 \pm 3.9 \mathrm{~mm}$ in the clomiphene group as compared to $19.1 \pm 3.5 \mathrm{~mm}$ in the letrozole group. The $p$ value was 0.276 and hence deemed not statistically significant.

\section{Number of Ovulations}

In the clomiphene group $7.3 \%$ achieved no ovulation, (Table 21 and Graph 21) 22.9\% achieved ovulation in the first cycle, $35.4 \%$ in the second cycle, $28.1 \%$ in the third cycle and only $6.3 \%$ in the fourth cycle. In the letrozole group, $1.9 \%$ achieved no ovulation, $22.1 \%$ in the first cycle, $47.1 \%$ in the second cycle, $26.0 \%$ in the third cycle and only $1.9 \%$ in the fourth cycle. Overall $2.03 \pm 1.03$ ovulations occurred in the clomiphene group against $2.07 \pm 0.85$ in the letrozole group, with a $p$ value of 0.787 which was statistically insignificant.

\section{Ovulation Per Cycle}

In the clomiphene group $11.5 \%$ of patients had less than $25 \%$ ovulation per cycle; (Table 22 and Graph 22) 17.7\% between 25 and $50 \% ; 31.3 \%$ between 50 and $75 \%$ and $39.6 \%$ achieved more than $75 \%$ ovulation per cycle. In the letrozole group, $2.9 \%$ of patients achieved ovulation in less than $25 \%$ cases per cycle; $25 \%$ in between 25 and $50 \%$; $38.5 \%$ between $50-75 \%$ and $33.7 \%$ achieved more 


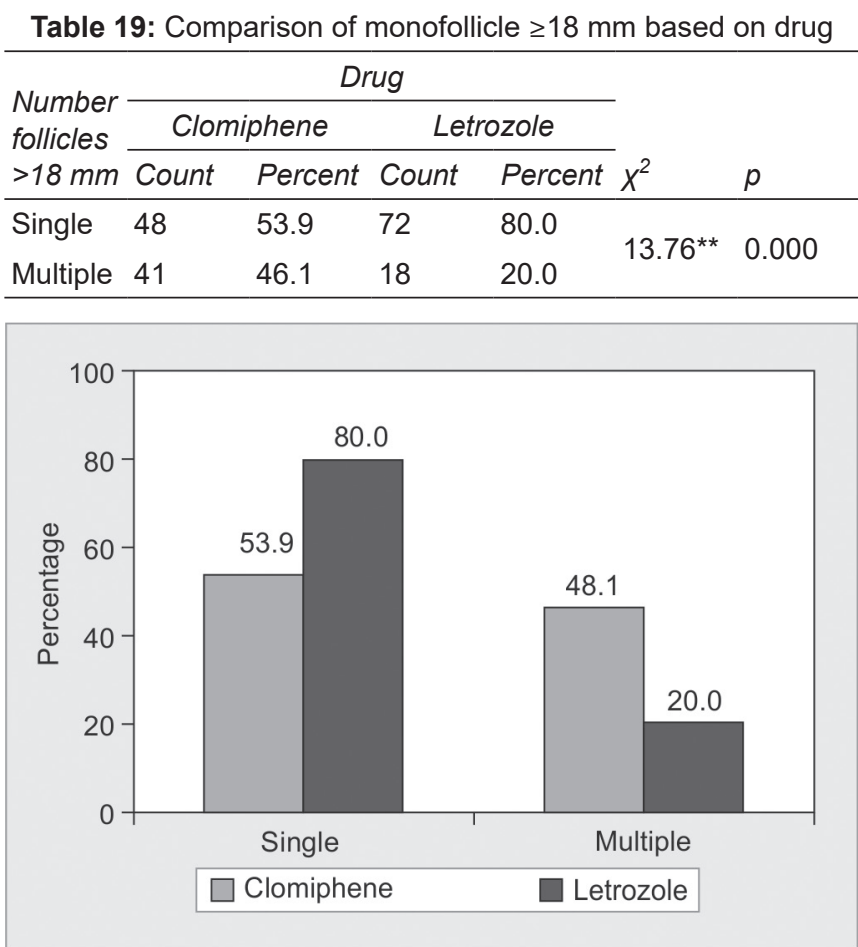

Graph 19: Comparison of monofollicle $\geq 18 \mathrm{~mm}$ based on drug

Table 21: Comparison of number of ovulations based on drug

\begin{tabular}{lllll}
\hline & \multicolumn{4}{c}{ Drug } \\
\cline { 2 - 5 } Number of & \multicolumn{2}{c}{ Clomiphene } & \multicolumn{2}{c}{ Letrozole } \\
\cline { 2 - 5 } Ovulations & Count & Percent & Count & Percent \\
\hline 0 & 7 & 7.3 & 2 & 1.9 \\
1 & 22 & 22.9 & 23 & 22.1 \\
2 & 34 & 35.4 & 49 & 47.1 \\
3 & 27 & 28.1 & 27 & 26.0 \\
4 & 6 & 6.3 & 2 & 1.9 \\
Mean \pm SD & $2.03 \pm 1.03$ & \multicolumn{3}{c}{$2.07 \pm 0.85$} \\
\hline
\end{tabular}

$\mathrm{t}=0.27, p=0.787$

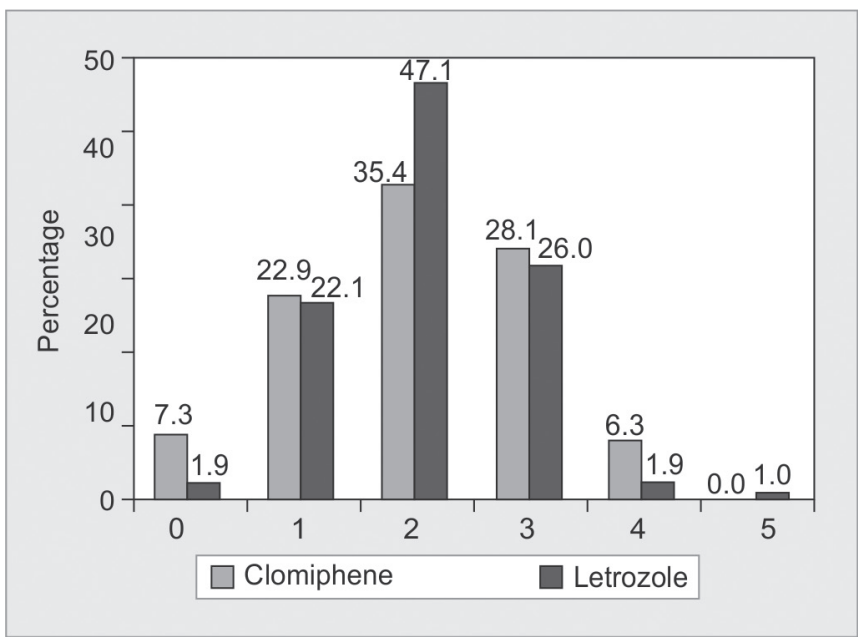

Graph 21: Comparison of number of ovulations based on drug

than $75 \%$ ovulation per cycle. On an average $69 \pm 0.31$ $\%$ patients achieved ovulation per cycle compared to $72 \pm 0.25 \%$ patients in letrozole group. The $p$ value was
Table 20: Comparison of size of DF based on drug

\begin{tabular}{|c|c|c|c|c|}
\hline \multirow[b]{3}{*}{ Size of DF } & \multicolumn{4}{|c|}{ Drug } \\
\hline & \multicolumn{2}{|c|}{ Clomiphene } & \multicolumn{2}{|c|}{ Letrozole } \\
\hline & Count & Percent & Count & Percent \\
\hline$<15$ & 13 & 13.5 & 12 & 11.5 \\
\hline $15-19.9$ & 46 & 47.9 & 41 & 39.4 \\
\hline $20-24.9$ & 32 & 33.3 & 47 & 45.2 \\
\hline Mean \pm SD & $18.6 \pm 3.9$ & & $19.1 \pm$ & \\
\hline
\end{tabular}

$\mathrm{t}=1.09 p=0.276$

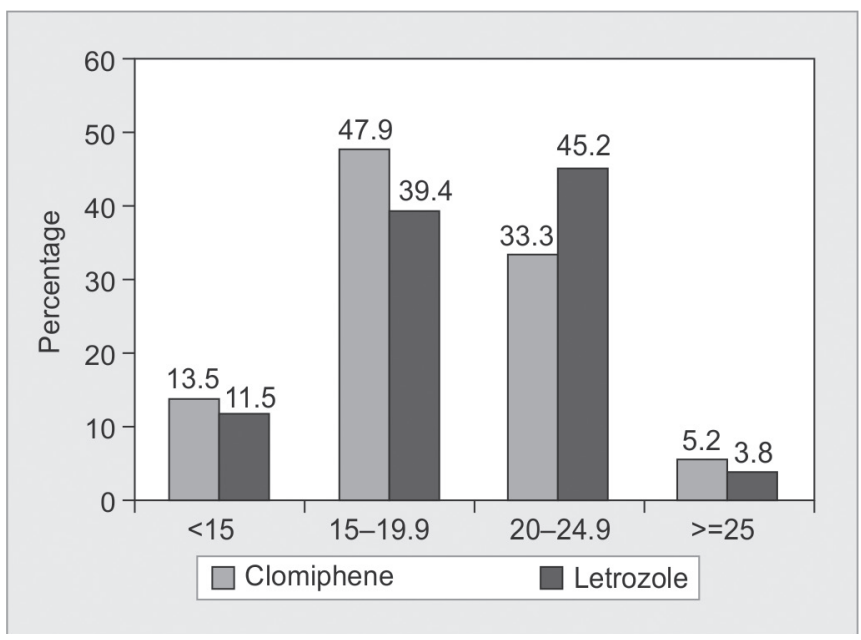

Graph 20: Comparison of size of DF based on drug

Table 22: Comparison of ovulation per cycle based on drug

\begin{tabular}{lllll}
\hline & \multicolumn{4}{c}{ Drug } \\
\cline { 2 - 5 } $\begin{array}{l}\text { Ovulation } \\
\text { per cycle }\end{array}$ & \multicolumn{3}{c}{ Clomiphene } & \multicolumn{3}{c}{ Letrozole } \\
\cline { 2 - 5 }$<25 \%$ & 11 & 11.5 & 3 & 2.9 \\
$25-50 \%$ & 17 & 17.7 & 26 & 25.0 \\
$50-75 \%$ & 30 & 31.3 & 40 & 38.5 \\
$>75 \%$ & 38 & 39.6 & 35 & 33.7 \\
Mean \pm SD & & $69 \pm 0.31$ & & $72 \pm 0.25$ \\
\hline
\end{tabular}

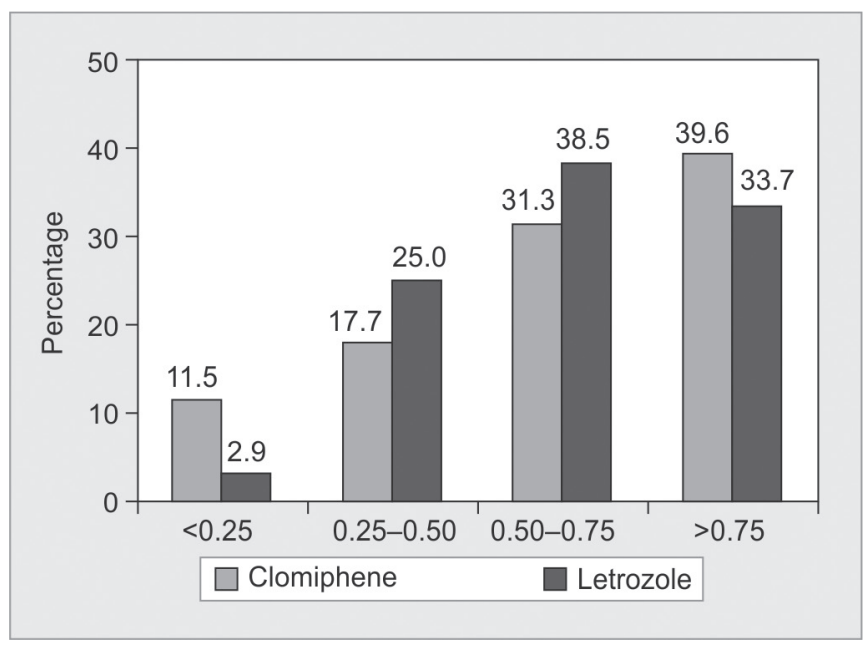

Graph 22: Comparison of ovulation per cycle based on drug

0.526 , hence the difference between the two groups did not transform into statistical significance. 
Table 23: Effectiveness of drug on ET

\begin{tabular}{llllllll}
\hline Drug & Stage & Mean & SD & $N$ & Mean difference & Paired t & $p$ \\
\multirow{2}{*}{ Clomiphene } & Pre-hCG & 7.49 & 2.76 & 96 & 3.03 & \multirow{2}{*}{14.66} & 0.000 \\
& After-hCG & 10.53 & 3.27 & 96 & & \multirow{2}{*}{21.56} & 0.000 \\
\hline \multirow{2}{*}{ Letrozole } & Pre-hCG & 6.89 & 2.32 & 104 & 3.64 & & \\
& After-hCG & 10.52 & 2.79 & 104 & & \\
\hline
\end{tabular}

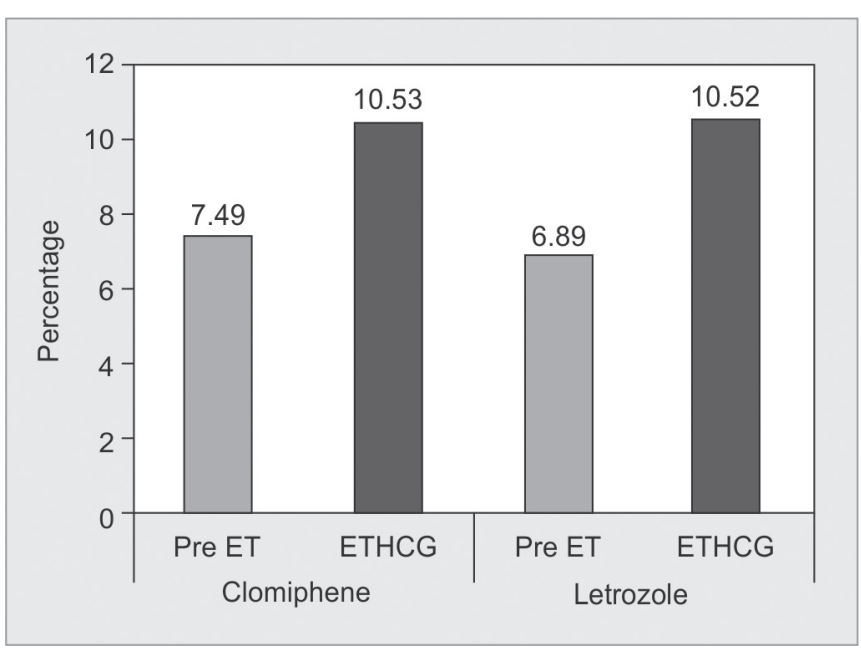

Graph 23: Effectiveness of drug on ET

\section{Endometrial Thickness}

The endometrial thickness is defined to be favorable when it is at least more than $8 \mathrm{~mm}$. (Table 23 and Graph 23) The endometrial thickness before and at the day of hCG administration following the use of either drug was compared. It was found to be $7.49 \pm 2.76$ pre hCG and $10.53 \pm 3.27$ on the day of hCG in the clomiphene group compared to $6.89 \pm 2.32$ pre hCG and $10.52 \pm$ 2.79 on the day of hCG in the letrozole group. The paired $\mathrm{t}$ values were 14.66 in the clomiphene group and 21.56 in letrozole group with a $p$ value of 0.000 which is deemed to be highly statistically significant (Table 24 and Graph 24). The mean difference achieved in endometrial thickness with the use of the drugs was 3.03 in the clomiphene group and 3.64 in the letrozole group. The $p$ value was 0.024 which was highly statistically significant.

\section{Number of Pregnancies}

In the clomiphene group, (Table 25 and Graph 25) 46.9\% achieved no pregnancy, $44.8 \%$ achieved pregnancy in at least one cycle, $5.2 \%$ in 2 cycles, $3.1 \%$ in 3 cycles. In the letrozole group $45.2 \%$ achieved no pregnancy, $50.0 \%$ achieved pregnancy in at least one cycle, $4.8 \%$ in 2 cycles, $0.0 \%$ in 3 cycles. The total pregnancies achieved was marginally higher in the letrozole group compared to the clomiphene group, however, the $p$ value was 0.593 hence the difference was not found to be statistically significant.
Table 24: Comparison of increase in ET based on drug

\begin{tabular}{llllll}
\hline Drug & Mean & $S D$ & $N$ & $t$ & $p$ \\
\hline Clomiphene & 3.03 & 2.03 & 96 & 2.27 & 0.024 \\
Letrozole & 3.64 & 1.72 & 104 & & \\
\hline
\end{tabular}

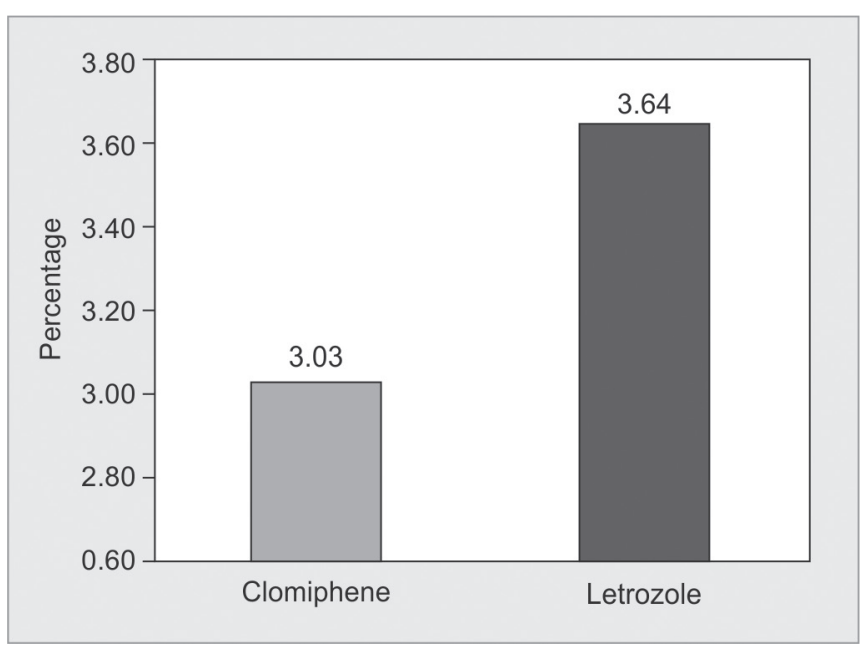

Graph 24: Comparison of increase in ET based on drug

\section{Pregnancy Per Cycle}

In the clomiphene group less than $25 \%$ pregnancy rate was achieved per cycle in $58.3 \%$; (Table 26 and Graph 26) between $25-50 \%$ in $30.2 \%$; between 50 and $75 \%$ in $6.3 \%$, more than $75 \%$ in $5.2 \%$, with a mean pregnancy achieved per cycle in $24 \pm 0.28 \%$ of patients. In the letrozole group less than $25 \%$ pregnancy rate was achieved per cycle in $56.7 \%$; between 25 and $50 \%$ in $34.6 \%$; between 50 and $75 \%$ in $1.9 \%$, more than $75 \%$ in $6.7 \%$ with a mean pregnancy achieved per cycle in $24 \pm 0.28 \%$ of patients. The $p$ value was 0.945 and hence found to be statistically insignificant.

\section{Rate of Miscarriages}

In the clomiphene group in $83.3 \%$ patients, (Table 27 and Graph 27) there was no pregnancy loss; in $12.5 \%$ the pregnancies achieved per cycle ended in at least miscarriage, and in $4.2 \%$ the pregnancies achieved ended in miscarriage in 2 or more cycles.

In the letrozole group in $84.6 \%$ patients, there was no pregnancy loss; in $14.4 \%$ the pregnancies achieved per cycle ended in at least miscarriage, and in 1.0\% the pregnancies achieved ended in miscarriage in 2 or more cycles. 
Table 25: Comparison of Number of pregnancy based on drug

\begin{tabular}{llcll}
\hline & \multicolumn{4}{c}{ Drug } \\
\cline { 2 - 5 } Number of & \multicolumn{3}{c}{ Clomiphene } & \multicolumn{2}{c}{ Letrozole } \\
\cline { 2 - 5 } pregnancy & Count & Percent & Count & Percent \\
\hline 0 & 45 & 46.9 & 47 & 45.2 \\
1 & 43 & 44.8 & 52 & 50.0 \\
2 & 5 & 5.2 & 5 & 4.8 \\
3 & 3 & 3.1 & 0 & 0.0 \\
Mean \pm SD & & $0.65 \pm 0.73$ & & $0.6 \pm 0.58$ \\
\hline
\end{tabular}

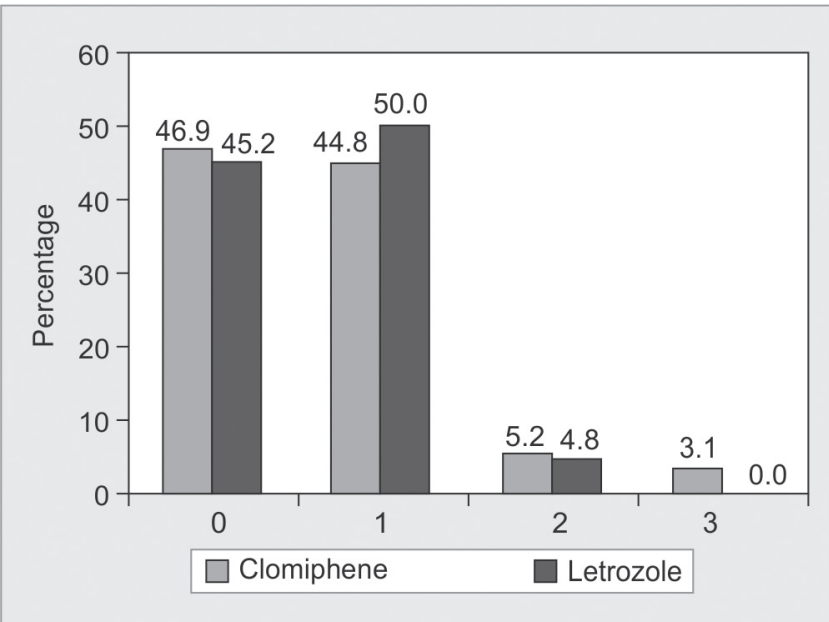

Graph 25: Comparison of number of pregnancy based on drug

Table 27: Comparison of number of miscarriages based on drug

\begin{tabular}{lllll}
\hline & \multicolumn{4}{c}{ Drug } \\
\cline { 2 - 5 } $\begin{array}{l}\text { Number of } \\
\text { abortion }\end{array}$ & \multicolumn{3}{c}{ Clomiphene } & \multicolumn{2}{c}{ Letrozole } \\
\cline { 2 - 5 } & Count & Percent & Count & Percent \\
\hline 0 & 80 & 83.3 & 88 & 84.6 \\
1 & 12 & 12.5 & 15 & 14.4 \\
2 & 4 & 4.2 & 1 & 1.0 \\
Mean \pm SD & $0.21 \pm 0.5$ & & $0.16 \pm 0.4$ \\
\hline
\end{tabular}

$\mathrm{t}=0.7, p=0.482$

On an average in $0.21 \pm 0.5 \%$ cases the pregnancy terminated in miscarriage in clomiphene group compared to $0.16 \pm 0.4 \%$ cases in the letrozole group.

The $p$ value of 0.482 did not show any statistically significant difference.

\section{DISCUSSION}

This study was conducted in a tertiary care multidisciplinary corporate hospital. As a result, only patients belonging to higher socioeconomic status were studied.

- Follicular number and size: In our study compared with letrozole, the use of clomiphene led to a significant increase in the number of developing and mature follicles (14 and $18 \mathrm{~mm}$ follicles). However monofollicular development was highly statistically significant in the letrozole group.
Table 26: Comparison of Pregnancy per cycle based on drug

\begin{tabular}{|c|c|c|c|c|}
\hline \multirow{3}{*}{$\begin{array}{l}\text { Pregnancy } \\
\text { per cycle }\end{array}$} & \multicolumn{4}{|c|}{ Drug } \\
\hline & \multicolumn{2}{|c|}{ Clomiphene } & \multicolumn{2}{|c|}{ Letrozole } \\
\hline & Count & Percent & Count & Percent \\
\hline$<25 \%$ & 56 & 58.3 & 59 & 56.7 \\
\hline $25-50 \%$ & 29 & 30.2 & 36 & 34.6 \\
\hline $50-75 \%$ & 6 & 6.3 & 2 & 1.9 \\
\hline$>75 \%$ & 5 & 5.2 & 7 & 6.7 \\
\hline Mean \pm SD & \multicolumn{2}{|l|}{$24 \pm 0.28$} & \multicolumn{2}{|c|}{$24 \pm 0.28$} \\
\hline
\end{tabular}

$\mathrm{t}=0.07 p=0.945$

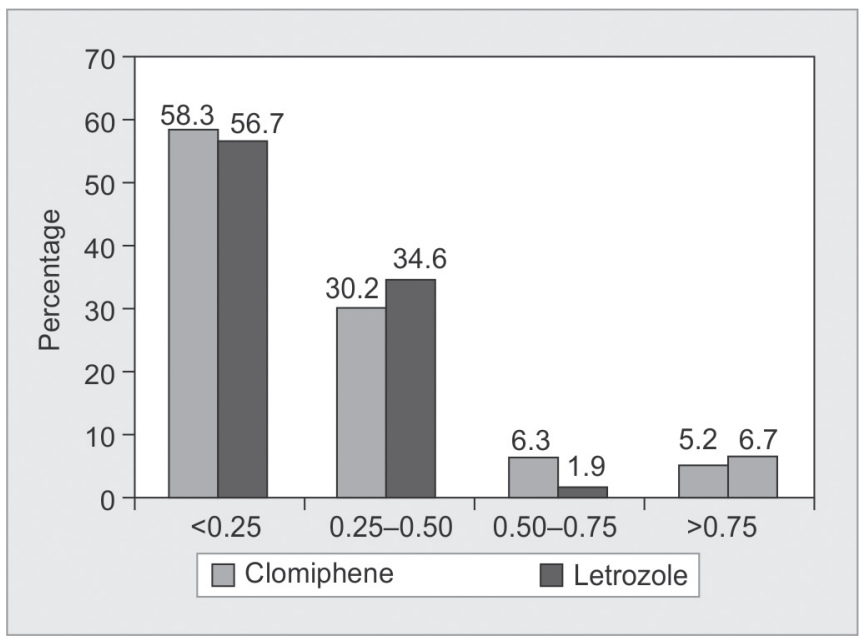

Graph 26: Comparison of pregnancy per cycle based on drugage

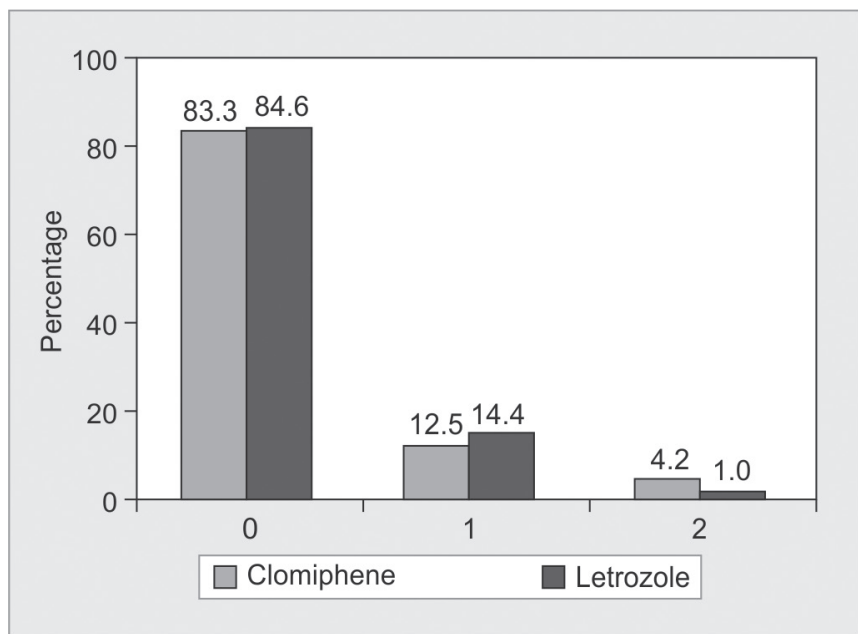

Graph 27: Comparison of number of abortion based on drug

\section{Endometrial Thickness}

The endometrial thickness achieved after letrozole was found to be highly significant statistically.

Mitwally and Casper showed a similar effect of letrozole on the endometrium. ${ }^{52}$ Cortinez et al. ${ }^{53}$ found normal morphological features of the endometrium and full expression of pinopodes during the implantation window when letrozole was used. On the other hand, no significant difference was noted in other studies in regard to the effect of either drug on the endometrium. ${ }^{54,55}$ 
$\mathrm{Al}$ Fouzan et al. ${ }^{56}$ reported better results in the letrozole group [for the number of developing and mature follicles] than in the clomiphene citrate group.

The size of the dominant follicle achieved in either group also lacked statistical significance.

- A number of cycles needed to achieve pregnancy: There was no statistically significant difference in the number of cycles needed to achieve pregnancy in either cycle. The ovulation rate per cycle was also not statistically significantly different in the two groups

- Pregnancy rate: In our study, the greater number of mature follicles in the clomiphene group did not result in increased pregnancy rate. On the contrary, the number of pregnancies achieved was marginally higher in the letrozole group, but the difference was not found to be statistically significant. The total number of pregnancy per cycle, however, showed no difference between the two groups

The total number of pregnancy losses was also similar in either group. Bayar et al. reported similar results in women with ovulatory infertility. ${ }^{57}$

There was one quadruplet gestation and one twin gestation in the clomiphene group $(0.02 \%)$. There was no instance of multiple gestations in the letrozole group. However, this data on multiple gestations was not sufficient for an analysis hence no statistical significance could be attached to the same.

In another study, Mitwally and Casper ${ }^{48,58}$ reported improved response to exogenous FSH stimulation with letrozole cotreatment in poor ovarian responders. Mitwally et al..$^{59}$ reported similar findings; although endometrial thickness was decreased, no negative effect on pregnancy rates was noted in this study. However, when letrozole was compared with clomiphene combined with gonadotrophin, Nejad and Bedaiwy et al. ${ }^{60,61}$ reported that the number of mature follicles and serum E2 level on the day of hCG administration was statistically significantly lower in the letrozole group than the clomiphene group.

Information on the teratogenic capacity of letrozole in humans is lacking, but animal studies have shown that low doses of letrozole are effective in inducing noxious effects on the developing conceptus. ${ }^{47}$ In the rat, teratogenic effects, including fetal domed head and cervical/ centrum vertebral fusion, resulted from exposure to 0.03 $\mathrm{mg} / \mathrm{kg}$. In the rabbit, embryotoxic effects were induced by exposure to $0.002 \mathrm{mg} / \mathrm{kg}$ (approximately $1 / 100,000$ the daily maximum recommended human dose on an $\mathrm{mg} / \mathrm{m}^{2}$ basis). Mitwally et al. ${ }^{59}$ reported favorable pregnancy outcomes and low multiple gestation rates with aromatase inhibitors for ovulation stimulation. Clomiphene citrate has been reported to elicit various ocular side effects in $1.5-10 \%$ of patients. ${ }^{58}$

The cost of letrozole is much higher than clomiphene citrate especially when higher doses of letrozole are required (Rs 33 per $2.5 \mathrm{mg}$ tablet of letrozole compared to Rs 14.50 per $100 \mathrm{mg}$ tablet of clomiphene citrate).

Bedaiwy et al. ${ }^{61}$ have suggested that a letrozole-FSH combination would be more cost effective than FSH alone for ovulation stimulation in intrauterine insemination cycles.

There was no instance of ovarian hyperstimulation syndrome in either group.

There were no incidences of congenital anomalies seen in either group.

\section{CONCLUSION}

Our study found the following advantages namely better endometrial thickness, monofollicular development, slightly higher pregnancy rates (though not statistically significant), no multiple gestations in the use of letrozole rather than clomiphene as a first line treatment for inducing ovulation in women with PCOS. There were no incidences of OHSS or congenital malformations in either group.

\section{RECOMMENDATIONS}

Letrozole can be used as a first line drug for ovulation induction in women with PCOS, who are at increased risk of hyperstimulation and multiple gestations with drugs like clomiphene citrate and gonadotropins. The doses for letrozole which have been widely studied are $2.5 \mathrm{mg}$ twice daily or $5 \mathrm{mg}$ once daily.

Further studies in this field are however warranted with regard to determining the optimum dose of letrozole,definitive evidence to rule out teratogenic effect of letrozole, if any, means to make the treatment with letrozole more cost-effective and whether or when to combine letrozole with gonadotropins with the aim of reducing the cost as well as increasing the success of induction.

Studies related to the same are underway around the world, to solve the above problems and other issues related to the bane of infertility.

The final word of the ideal drug for ovulation induction in women with polycystic ovarian syndrome, however, remains yet to be said!

\section{REFERENCES}

1. Balen AH, Conway GS, et al. Polycystic ovary syndrome: the spectrum of the disorder in 1741 patients. Hum Reprod 1995;10:2107-2111

2. Polson DW, Adams J, et al. Polycystic ovaries-a common finding in normal women. Lancet 1988;1:870-872.

3. Farquhar CM, Birdsall M, et al . The prevalence of polycystic ovaries on ultrasound scanning in a population of randomly selected women. Aust N Z J Obstet Gynaecol 1994;34:67-72.

4. Michelmore KF, Balen AH, et al. Polycystic ovaries and associated clinical and biochemical features in young women. Clin Endocrinol Oxf 1999;51:779-786. 
5. Franks S. Polycystic ovary syndrome.New England Journal of Medicine 1995;333:853-861.

6. Sperling L, Heimer W. Androgen biology as a basis for the diagnosis and treatment of androgenic disorders in women. Int J Am Acad Dermatol 1993;28:669-681.

7. Nelson VL, Legro RS, et al. Augmented androgen production is a stable steroidogenic phenotype of propagated theca cells from polycystic ovaries. Mol Endocrinol 1999;13:946-957.

8. Gilling-Smith C, Willis DS, et al. Hypersecretion of androstenedione by isolated thecal cells from polycystic ovaries. J Clin Endocrinol Metab 1994;79:1158-1165

9. Gilling-Smith C, Story $\mathrm{H}$, et al. Evidence for a primary abnormality of thecal cell steroidogenesis in the polycystic ovarian syndrome.Clin Endocrinol 1997;47:93-99

10. Conway GS, Clark PM, et al. Hyperinsulinemia in the polycystic ovary syndrome confirmed with a specific immunoradiometric assay for insulin. Clinical Endocrinology [Oxford] 1993;38:219-222.

11. Schwartz R. Acanthosis nigricans. J Am Acad Dermatol 1994; 31:1-19.

12. Burghen GA, Givens JR, et al. Correlation of hyperandrogenism with hyperinsulinism in polycystic ovarian disease. J Clin Endocrinol Metab 1980; 50:113-116.

13. Coulam CB, Annegers JF, et al. Chronic anovulation syndrome and associated neoplasia. Obstet Gynecol 1983;61:403-407.

14. Azziz R. The Rotterdam 2003 Criteria for defining PCOS. Can or how to define syndrome. J Clin Endocrinol MetabFirst Published January 2003;17:2006.

15. The Rotterdam ESHRE/ASRM-sponsored PCOS consensus workshop Group , Revised consensus or diagnostic criteria and long term health risks related to polycystic ovary syndrome, 2003.

16. Fulghesu AM, Ciampelli M, et al. A new ultrasound criteria for the diagnosis of polycystic ovary syndrome: the ovarian stroma total area ratio. Fertil Steril 2001;76:326-331.

17. Burton J, Shuster S. The relationship between seborrhea and acne vulgaris. British journal of Dermatol 1971;84:600-602.

18. Simpson N, Barth J. Hair patterns: hirsuties and androgenic alopecia. In R Dawber (ed): Diseases of the hair and scalp. Oxford: Blackwell Science 1997; 67-122.

19. Dunaif A, Hoffman A, et al. Clinical, biochemical and ovarian morphologic features in women with acanthosis nigricans and masculinization. Obstetrics and gynaecology 1985;66;545-552.

20. Morin-Papunen LC, et al. Endocrine and metabolic effects of metformin vs. ethinyl estradiol-cyproterone acetate in obese women with polycystic ovarian syndrome: randomized study. JClin Endo and Metab 2000;85(9):3161-3168.

21. Pasquali R, Gambineri A, et al. Effect of long term treatment with metformin added to hypocaloric diet on body composition, fat distribution and androgen and insulin levels in abdominally obese with and without polycystic ovary syndrome. J of Clin Endo and Metab 2000;85(8):2767-2774

22. Tasdemir S, Ficicioglu C, et al. The effect of metformin treatment to ovarian response in cases with PCOS. Arch Gynaecol Obstet 2003;23.

23. Barbieri R L. Metformin for the treatment of polycystic ovary syndrome. Obstet Gynaecol 2003;101(4)785-793.

24. Greenbhatt RB. Chemical induction of ovulation .Fertil Steril 1961;12:402.

25. Gjonaess H. Polycystic ovarian syndrome treated by ovarian electrocautery through laparoscopy. Fertil Steril 1984;41:20-25.
26. Abdel Gadir A, Mowafi RS, et al. Ovarian electrocautery versus human menopausal gonadotrophins and pure follicle stimulating hormone therapy in the treatment of patients with polycystic ovarian disease.Clin Endocrinol [Oxf.] 1990;33:585592.

27. Lessing JB, Amit A, et al. Avoidance of cancellation of potential hyperstimulation cycle by conversion to in vitro fertilizationembryo transfer. Fertil Steril 1991;56(1):75-78.

28. Kyei-Mensah A, Maconochie N, et al. Transvaginal three dimensional ultrasound: reproducibility of ovarian and endometrial volume measurements. Fertil Steril 1996;5:718-722

29. Levene MI, Wild J, et al. Higher multiple births and the modern management of infertility in Britain. Br J Obstet Gynaecol 1992; 99:607-613

30. Botting BJ, Macfarlane AJ, et al. [eds. . Three, four and more: a study of triplet and higher order births. HMSIO, London 1990.

31. Sammour A, Biljan MM, et al. Prospective randomized trial comparing the effects of letrozole and clomiphene citrate on follicular development, endometrial thickness and pregnancy rate in patients undergoing superovulation prior to intrauterine insemination. Fertil Steril 2001;76(suppl-1):S110.

32. Stein IF, Leventhal ML. Amenorrhoea associated with PCOS Am J Obst and Gynaecol 1935;29:181-191.

33. Dahlgren E, Johannsen S, et al . Women with polycystic ovary disease wedge resected in 1956-1965: A long term follow up focusing on natural history and circulating hormones . Fertil Steril 1992;57:505-513.

34. Donesky BW, Adashi EY. Surgically induced ovulation in the polycystic ovary syndrome: wedge resection revisited in the age of laparoscopy. Fertil Steril 1995;63:439-463

35. Stein IF, Cohen MR, et al. Results of bilateral ovarian wedge resection in 47 cases of sterility. Am J Obst and Gynae 1948; 58:267-273.

36. Chereau A. Memoire pour server a I' Etude des Maladies des ovaries. Paris: Fortin.Masson and Cie, 1844.

37. Dickey RP, Taylor SN, et al. Incidence of spontaneous abortion in clomiphene pregnancies. Hum Reprod 1996; 11:2623-2628.

38. Hammond MG. Monitoring techniques for improved pregnancy rates during clomiphene ovulation induction. Fertil Steril 1984;42:499-508

39. Hammond M, Halme J, et al. Factors affecting the pregnancy rate in clomiphene citrate induction of ovulation.Obstet Gynaecol 1983;62:196-202

40. Adams J, Franks S, et al. Multifollicular ovaries: clinical and endocrine features and response to pulsatile gonadotrophin releasing hormone. Lancet 1985;(2):1375-1378

41. Badawy A, Aal IA, et al. Clomiphene citrate or letrozole for ovulation induction in women with polycystic ovarian syndrome? A prospective randomized trial. 14th World Congress On In Vitro Fertilization And Third World Congress On In Vitro Maturation, 2007.

42. Randall JM ,Templeton A. Cervical mucus score and in vitro sperm mucus interaction in spontaneous and clomiphene citrate cycles. Fertil Steril 1991;56:465-468.

43. Gonen Y, Casoer RF. Sonographic determination of an adverse effect of clomiphene citrate on endometrial growth. Hum Reprod 1990;5:670-674.

44. Rossing MA, Daling JR, et al. Ovarian tumours in a cohort of infertile women. N Engl J Med 1994;331:771-776

45. Mitwally MFM, Casper RF. Aromatase inhibition: a novel method of ovulation induction in women with polycystic ovarian syndrome. Report Technol 2000:10:244-247.

46. Okman KT, Kucuk M, et al. Comparison of the effects of letro- 
zole and clomiphene citrate on ovarian follicles, endometrium and hormone levels in the rat. Fertil Steril 2003; 80:1330-1332.

47. Tulandi T, Martin J, et al. Congenital malformations among 911 newborns conceived after infertility treatment with letrozole or clomiphene citrate. Fertil Steril 2006;85:1761-1765.

48. Mitwally MFM, Casper RF. The use of an aromatase inhibitor for induction of ovulation in cases of clomiphene failure [abstract]. In program and abstracts of the 16th Annual Meeting of the European Society for Human Reproduction and Embryology [ESHRE]. Bologna. Italy June 2000;15:71.

49. Mitwally MFM, Casper RF. The aromatase inhibitor, letrozole, decreases FSH dose required for ovarian superovulation. In: Proceedings of the 46th Annual Meeting of the Canadian Fertility and Andrology Society, September 2000; New foundland, Canada.

50. Mitwally MFM, Casper RF. Aromatase inhibition improves response to controlled ovarian hyperstimulation without the antioestrogenic effects of clomiphene citrate [abstract]. J Soc Gynecol Investi 2001:8:85A

51. Mitwally MFM, Casper RF . Aromatase inhibition improves ovarian response to FSH a potential option for low responders during ovarian stimulation.Fertil Steril 2001;75:(4 Suppl1):S8-S9.

52. Mitwally MRM, Casper RF. Use of aromatase inhibitor for ovulation induction in patients with an inadequate response to clomiphene citrate. Fertil Steril 2001;75:305-309.

53. Cortinez I, De Carvalho D, et al. Hormonal profile and endometrial morphology in letrozole controlled ovarian hyperstimulation in ovulatory infertile patients. Fertil Steril. 2005;83:110-115.
54. Fischer SA, Reid RL, et al. A randomized double blind comparison of the effects of clomiphene citrate and the aromatize inhibitor letrozole on ovulatory function in normal women. Fertil Steril 2002;78:280-285.

55. Kilic Okman T, Kucuk M, et al. Comparison of the effects of letrozole and clomiphene citrate on ovarian follicles, endometrium and hormone levels in the rat. Fertil Steril 2003;80:13301332.

56. Al-Fouzan $\mathrm{H}, \mathrm{Al}-\mathrm{Khadouri} \mathrm{M}$, et al. A randomized trial of letrozole versus clomiphene citrate in women undergoing superovulation. Fertil Steril 2004;82:1561-1563.

57. Bayar U, Tanriverdi HA, et al. Letrozole vs. clomiphene citrate in patients with ovulatory infertility .Fertil Steril. 2006;85:10451048.

58. Bishai R, Arbour L, et al. Intrauterine exposure to clomiphene and neonatal persistent hyperplastic primary vitreous. Teratology 1999;60:143-145.

59. Mitwally MFM, Biljan M, et al. Pregnancy outcome after the use of an aromatase inhibitor for ovulation stimulation. Am J Obstet Gynecol 2005;192:381-386.

60. Nejad TE, Abediasl Z, et al. Comparison of the efficacy of the aromatase inhibitor letrozole and clomiphene citrate gonadotropins in controlled ovarian hyperstimulation: a prospective, simply randomized, clinical trial. J Assist Reprod and Genet 2008;25(5):187-190.

61. Bedaiwy M, Forman R, et al. Cost effectiveness of aromatase inhibitor cotreatment for controlled ovarian stimulation . Human Reprod 2006;21:2838-2344. 